\title{
EVALUATION OF FISHWAY DESIGNS FOR DOWNSTREAM PASSAGE OF SPRING CHINOOK SALMON AND STEELHEAD TROUT SMOLTS, 1987
}

Fianl Report

Prepared By

J. L. Congleton, Principal Investigator

E. J. Wagner, Graduate Assistant

R. R. Ringe, Fishery Biologist

Idaho Cooperative Fish and Wildlife Research Unit

Department of Fish and Wildlife Resources

College of Forestry, Wildlife and Range Sciences

University of Idaho

Moscow, Idaho $\mathbf{8 3 8 4 3}$

\author{
Prepared For \\ Dale Johnson, Project Manager \\ U.S. Department of Energy \\ Bonneville Power Administration \\ Division of Fish and Wildlife \\ P.0. Box 3621 \\ Portland, Oregon 97208 \\ Project No. 86-47 \\ Contract No. DE-AI79-86BP 64234
}




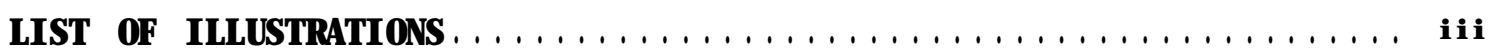

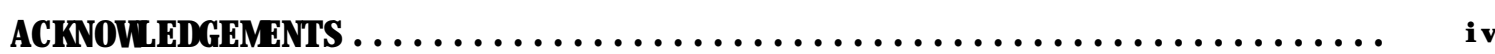

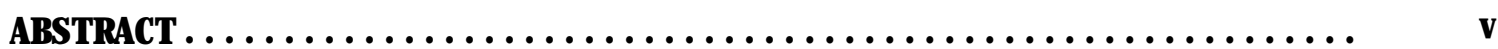

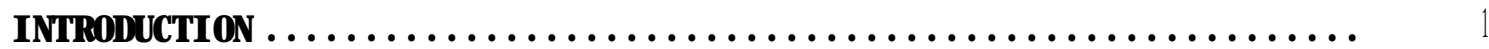

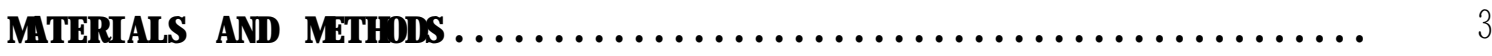

Desi gn of Test Fl unes $\ldots \ldots \ldots \ldots \ldots \ldots \ldots \ldots \ldots \ldots \ldots \ldots \ldots \ldots \ldots$

Procedures for Fl une Tests $\ldots \ldots \ldots \ldots \ldots \ldots \ldots \ldots \ldots \ldots \ldots \ldots$

Determinati on of PI asma Corti sol and Lactate Concentrati ons .... . 5

Criteria for Descaling ........................ 6

Anal ysi s of Cortisol and Descali ng Data............... 6

Behavi or of Adul t Chi nook Sal non i $n$ Fl unes ............. 7

Passage of Debris Through Fl unes $\ldots \ldots \ldots \ldots \ldots \ldots \ldots \ldots \ldots \ldots \ldots$

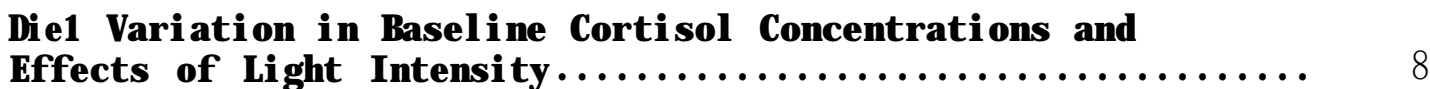

Basel i ne Corti sol Concentrati ons i n Chi nook Sal non......... a a

Corti sol Concentrati ons i n Chi nook Sal mon and Steel head

Trout Hel d i $n$ Raceways ............................. 8

Effect of Reduced Li ght Intensity on Corti sol

Concent rati ons i n Chi nook Sal mon and Steel head Trout ........ 9

Corti sol Concentrati ons i n I sol at ed Chi nook Sal non . . . . . . . . . 10

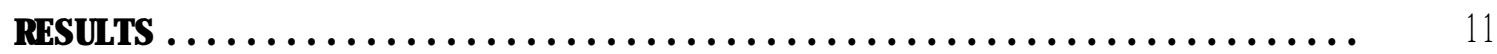

PI asna Corti sol Concentrati ons Before and After Fl une Passage... 11

Chi nook Sal mon............................. 11

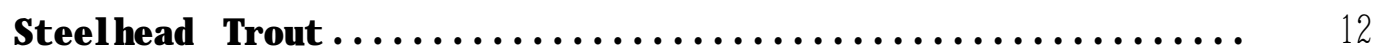

Rate of Passage of Snol ts through Fl unes ............... 13

PI asma Lactate Concentrati ons Before and After FI une Passage.... 14 
Descal ing of Snolts in Fl unes.................... 15

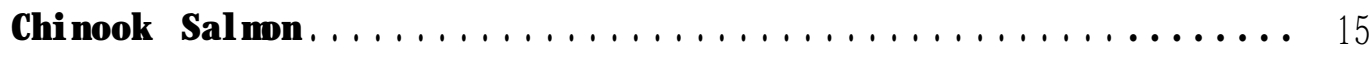

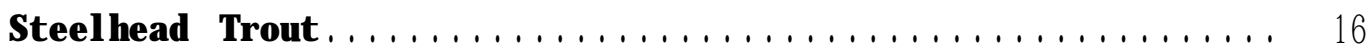

Behavi or of Adult Chi nook Sal non i $n$ Fl unes............. 16

Passage of Debris through Fl unes $\ldots \ldots \ldots \ldots \ldots \ldots \ldots \ldots \ldots \ldots \ldots$

Diel Vari ati on in Basel i ne Corti sol Concentrations and Ef fects

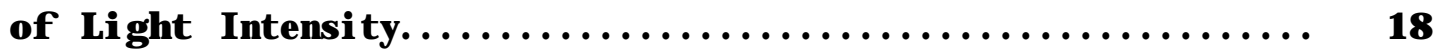

Corti sol Concentrati ons i n Chi nook Sal non Hel d i n

168- $L$ Tanks................................... 18

Corti sol Concentrati ons i n Chi nook Sal non and Steel head

Trout Hel d i $n$ Racenays.............................. 18

Effect of Reduced Li ght I ntensi ty on Corti sol Concent rati ons i $n$ Chi nook Sal mon and Steel head Trout. ................. 18

Corti sol Concentrati ons i n I sol at ed Chi nook Sal non. ......... 22

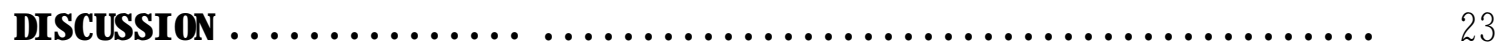

Effects of Fl une Passage on Corti sol Concentrations ......... 23

Descal ing of Snolts i $n$ Fl unes .................... 25

Behavi or of Adul $t$ Chi nook Sal non i $n$ Fl ues. . . . . . . . . . . 26

Passage of Debris Through Fl umes................... 26

Di el Vari ation i n PI asma Corti sol Concentration and Effects

of Li ght I ntensity................................ 26

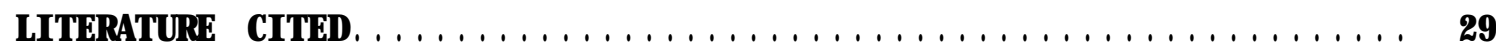

\section{APPENDI CES}

Appendi x A: Hydraul i c Anal ysi s of Fl unes

Appendi x B: Anal ysi s of Vari ance Tabl es for Sel ected Tests

Appendi x C: Summary of PI asma Corti sol Concentrati on Dat a for 1985 and $1987 \mathrm{Fl}$ une Tests 


\section{LIST OF ILLUSTRATIONS}

1. Schematic of the three test flunes.

2. Diel fl uctuations in pl asma corti sol concentrations i n chi nook sal non snol ts hel $d$ in darkened and undarkened 168- $L$ tanks.

3. Diel fl uct uati ons i n pl asma corti sol concentrations i n chi nook sal non snol ts hel d in covered and uncovered raceways.

4. Diel fl uct uati ons i $n$ pl asma corti sol concent rations in steel head trout snol ts hel $d$ in covered and uncovered raceuays.

5. Compari son of mean corti sol concentrati ons ( $\pm S E$ ) bet ween basel i ne and fl une post passage sampl es in chi nook sal non sampl ed in 1985 and 1987 during the dayti me (uncovered i n 1985; parti al I y darkened (PD), or conpl et el y darkened (CD) i n 1987) or ni ghtti me. 


\section{ACKNOWLEDGEMENTS}

We thank T. Bari I a, R. Enmert, J. Ferguson, D. J ohnson, $M$ Li ndgren, $R$. Ri nge, and $S$. Vill is for assi stance in pl anning and carrying out thi s project. 


\section{ABSTRACT}

The stress response of chi nook sal mon and steel head trout snol ts to passage through three different fl unes was tested by assayi ng $\mathrm{pl}$ asma cortisol concentrati ons before and after fl une passage. In addition, descal ing of $f i$ sh was recorded bef ore and after $f I$ une passage, and the ability of the fl unes to pass adul t chi nook sal non and debris was deterni ned. The three fl unes vere a corrugated netal fl une ( $\mathrm{OMF}$ ), a 4foot wi de baffled $f \mid$ une (BF4), and a Z-foot wi de baffled $f \mid$ une (BF2). Each fl une was tested under three conditions: 1) at ni ght, 2) during the day with a perforated metal cover, which reduced the amount of I i ght entering the fl une by about hal f (partial Iy darkened), and 3) during the day with the perforated cover and an addi ti onal double I ayer of bl ack pl asti c (compl et el y darkened).

Pl asma corti sol concentrati ons were not si gnificantly el evated in chi nook sal non snol ts after passage through any of the $f$ l unes $(P>0.2$, ANOVA). In dayti ne tests of parti al ly and compl etel y darkened fl unes corti sol concentrati ons were consi stentl y decreased fol I owing $\mathrm{fl}$ une passage. We attribute this to pre-test stress (hol ding of fi sh in smal I tanks) and to the absence of a strong stress response to fl une passage. Fl une desi gn did not have a si gnificant effect on corti sol concentrations $(P=0,9)$. Tot al darkening of the $f($ unes duri ng dayti ne uas benefici al: corti sol concentrati ons were l ower $(P=0.03)$ in chi nook sal mon snol ts passing through compl etely darkened fl unes than in snol ts passing through partially darkened fl unes.

In steel head trout snol ts, pl asna corti sol concentrations were si gni fi cantl y el evated af ter passage through the $\mathrm{fl}$ umes, and $\mathrm{fl}$ une desi gn di d have a si gni fi cant ef fect ( $P<0, \infty 00$, ANOVA). Corti sol concentrati ons were nost increased in fi sh that passed through the BF2, fol I oved by fi sh that passed through the BF4. The snal lest increase occured in fish that passed through the OMF. Compl ete darkening of the fl unes during dayti ne tests did not have a si gnificant effect on corti sol concentrations ( $P=0,4)$.

Pl asma corti sol concent rati ons were si gni fi cantl y hi gher in dayti ne than i n ni ghtti ne sampl es of chi nook sal mon snol ts hel d i n darkened and undarkened tanks and raceways. Thi s di el corti sol cycle was unaffected by light intensity. The corti sol response to passage through darkened fl umes was greater in ni ghtti me than in dayti me tests wi th both speci es.

None of the fl umes tested caused descal ing of $f i$ sh. Descal ing was measured in two ways: as mean percent of body area descal ed, and as the percent of fish in a sample wi th greater than $5 \%$ descal ing in any of 10 body zones. Nei ther of these descal ing measures was si gni fi cantly increased after $\mathrm{fl}$ une passage, and $\mathrm{fl}$ une design di $\mathrm{d}$ not have a si gni fi cant ef $f$ ect. 
When woody debri s was i ntroduced i nt o the fI unes, a number of pi eces I odged in the tho baffled fl umes. Mbst of the pi eces that I odged i $n$ the BF4 were 1.3 to 2.4 neters i $n$ I ength. A I debri s passed freel y through the CHF. Adult chi nook sal mon $(N=3)$ passed through each of the fl umes in $5 \mathrm{~min}$ or l ess. 


\section{IMTRODUCTION}

The coll ecti on faci I ity at Little Goose Damfor downstream migrating chi nook sal mon (Oncorhvnchus tshauvtscha) and st eel head trout (Sal mo gai rdneri) snol ts wi I be rebui It in the near f ut ure and wi I I ncl ude a new bypass system to carry fish from the dam to the facility. Al ternative desi gns to the pressurized-pi pe bypass now in use at Little Goose Dam uere eval uated by Congl et on and Ri nge (1985). They tested a corrugated netal (CMF; tested at $3.4 \% \mathrm{sl}$ ope) and a baffled fl une (BF; tested at sl opes of 3. 4 and $8.3 \%$ and concl uded that:

1) I n dayti me tests, pl asma corti sol concentrations i $n$ both chi nook sal mon and steel head uere si gni fi cantly hi gher (i ndi cati ng a stronger stress response) after passage through the CMF than after passage through the baffled fl unes. In ni ghtti me tests, cortisol concentrations did not differ si gnificantly bet ween groups after passage through the CMF and baffl ed fl umes. These resul ts suggested that I i ght i nt ensi ty af fected pl asma corti sol concentrations and contri buted to the el evation of pl asma cortisol in fish passing through the CMF during daylight hours (the i nteri or of the unpai nted CMF was much brighter than the interior of the BF).

2) Descal ing of test fi sh was rel ati vel y l ow i $n$ both test fl unes, but sonewhat greater in the CMF than in the BF (day tests onl y). A hydraul i c anal ysi s by Army Corps of Engi neers personnel suggest ed that hydraul i c condi ti ons over the perforated dewatering pl ate at the termin of the CMF could have been responsible for the descal ing observed.

3) Fl oating debris passed readily through the CMF, but several water-l ogged sticks l odged in the baffled fl ume.

After revi ew of the 1985 studi es, the Fi sh Passage Comittee of the Col unbi a Basi n Fi sh and Vill il e Council asked several questions:

1) Could the increase in plasna cortisol concentrations in fish passing through the CMF during the dayti ne be reduced by darkening the interi or of the fl une?

2) Could the dewatering screens at the terminus of the CMF be modified to el i mate descal ing of fish?

3) How wel I nould a wi der baffled fl une pass debri s?

4) Wbul d adul t sal moni ds, parti cul arl y upst ream mi grati ng chi nook sal non, renai $n$ in a baffled fl une for extended periods, possibly detering the passage of $\mathrm{j}$ uveni l e $\mathrm{f} i \mathrm{sh}$ ?

In 1986 the Bonnevi Il e Power Admi ni strati on made f unds avai I abl e for further fl une testing ( see Appendi $x$ A for description of fl une nodi fi cati ons). These funds uere admi ni stered by the Ual I a WhI I a Di stri ct of the U.S. Army Corps of Engi neers, who modified the fI une testing 
faci I ity at Lower Grani te Dam and contracted wi th the I daho Cooperati ve Fish and $V^{\prime \prime} I d l$ ife Research Unit for testing of the flumes.

For the $1987 \mathrm{fl}$ une comparison tests, the i nteri or of the CMF was pai nted a dark gray-brown col or to reduce the bri ght ref I ecti ve gl are suspected to contri bute to i ncreased corti sol l evel s i n smol ts i 1985. Hydraul ic conditions at the terminus of the CMF were nodified to increase the depth of water over the dewatering pl ate and a new enl arged concrete sampl ing tank was constructed to el i mate I eakage probl ens and reduce turbul ence. The 2-foot wi de (0.61 m) baffled fl une (BF2) wi th a sl ope of 3. 4\% renai ned essenti al Iy the sane as tested in 1985, except that the i nt eri or was $I \mathrm{i}$ ned with $\mathrm{f} i$ bergl ass to reduce leakage and pai nted the sane col or as the CMF. The BF2 with an $8.3 \%$ sl ope was renoved and a new 4-foot wi de (1.22 m) baffled fl une (BF4) with a sl ope of $3.4 \%$ was constructed of concrete.

The performance of the $f($ umes was compared on the basi s of the following criteria:

1) Changes in pl asma cortisol concentrations (i ndi cati ve of a physi ol ogi cal stress response) i $\mathrm{n} f \mathrm{i} h \mathrm{t}$ hat passed through each $\mathrm{fl}$ une under three I i ght condi ti ons: ni ghtti me, parti al l y darkened i n dayt i me, and compl et el y darkened i n cayti ne. each flume.

2) Descaling or other physical damage to fi sh that passed through

3) Ti ne requi red for passage of snol ts through $f($ unes.

4) Ability of flumes to pass debris.

5) Behavi or of adul $t$ chi nook sal non i $n$ fl unes.

Several addi ti onal questi ons regarding the ef fects of I i ght i nt ensi ty and peri odi city on pl asma corti sol concent rations were addressed. Thi s i nf or mati on was needed to ai d i $\mathrm{n}$ i nterpretation of dat a on changes i $n$ pl asma corti sol in snol ts after passage through covered and uncovered fl unes ( 1 above).

1) Do pl asna corti sol concentrati ons in chi nook sal mon and steel head trout smol ts fl uct uate on a day-ni ght (di el) basi s?

2) If so, does the diel cortisol cycle conti nue in snol ts hel d in const ant darkness?

3) If the diel corti sol cycle is surpressed by constant darkness, to what extent must Iight intensi ti es be reduced to attai $n$ this effect?

4) If a diel cortisol cycle has a dayti me peak, is this a consequence of intraspecific aggressi ve behavi or that is dependent upon vi sual cont act? 


\section{MATER ALS AND METHODS}

A I tests were conducted at the fish passage facility of Lower Grani te Dam Garfi el d Co., Whshi ngt on, bet ueen Apri I 12 and May 21, 1987, in cooperation with personnel of the Army Corps of Engi neers.

\section{Design of Test Punes}

Three fl ume desi gns were eval uated by this study (Fi gure 1 and Appendi $x$ A). The first desi gn was a corrugated metal $f$ l ume (CMF) const ructed of 12-gauge al umi num wi th $1.3-\mathrm{cm} \mathrm{hi}$ gh corrugati ons on $6.7 \mathrm{~cm}$ centers. Thi s fl ume was $U$-shaped in cross section with a wi dth of $86 \mathrm{~cm}$ (2. 9 feet). The ot her tuo fl unes were square i $n$ cross secti on wi $t h$ baffles of mol ded $f i$ bergl ass that created a serpenti ne water fl ow One of these fl unes (BF4) was $1.22 \mathrm{~m}$ wi de ( 4 feet) with baffl es every $1.22 \mathrm{~m}$ on al ternate si des of the flune, and was constructed of concrete. The other baffled fl une (BF2) was $0.61 \mathrm{mw}$ de ( 2 feet) with baffles every $0.61 \mathrm{~m}$ and was constructed of pl ywood I i ned wi th fi bergl ass. Fl ous in the CMF, BF4, and BF2 were $0.85,0.71$, and $0.14 \mathrm{~m}^{3} / \mathrm{s}(30,25$, and 5 cubi c feet/s) respecti vel y. Al fl unes had a $3.4 \%$ sl ope. Perforated pl ate covered each of the fl une channel s, reduci ng the anount of i nci dent I i ght. The i nteri ors of al I fl unes were pai nted a dark gray-brown.

At the head of each $f I$ une were si $x$ 168- $L$ al umi num hol di ng tanks (91 $\mathrm{cm} \times 33 \mathrm{~cm}$ wi de and 48 to $64 \mathrm{~cm}$ in depth, with bott om sl opi ng toward door), f our of which had a rel ease nechani sm to open the downstream faci ng door. The tanks had opaque $f i$ bergl ass $I i d s$ and the overfl ow screens were covered with duct tape to excl ude I i ght. Wter from the Snake Ri ver was supplied to each tank at $0.55-0.60 \mathrm{~L} / \mathrm{s}$, nai nt ai $n i n g$ temperat ures at $11-$ 12 c. Bel ow the hol di ng tanks at the head of the BF2 and BF4 were sli di ng crouder screens used to force the snol ts to swi dounstream af ter rel ease. Rel ativel y high vel ocities at the head of the CMF precl uded the need for a crouder screen.

At the downstream end of each $f$ I une was a recei vi ng tank whi ch the fish entered after passing through the fl une. These tanks were desi gned to provi de a qui et resting area for the fi sh and vere suppl i ed with fresh water to mai ntai $n$ adequate oxygen concentrati ons and temperat ures. The horizontal di nensi ons were based on hydraul ic consi derati ons and di ffered for each fl une ( Fi g. 1). Whter depth varied from 1. 0-1. 4 m duri ng fl ume ooeration to $47 \mathrm{~cm}$ after shut of $f$. The tanks were covered with perforated al umi num $\mathrm{pl}$ ate and a doubl e I ayer of bl ack pol yet hel ene, whi ch reduced the nornal I i ght intensity ( up to 3800 I ux) to I-4 I ux.

\section{Procedures for $\mathrm{A}$ une Tests}

Chi nook sal mon and steel head trout smol ts were obtai ned from the gat ewel Is of Lower Grani te Dam bet ueen 1900-0100 hours by Nati onal Mari ne Fi sheries Servi ce personnel using a crane-operated sampling basket. 


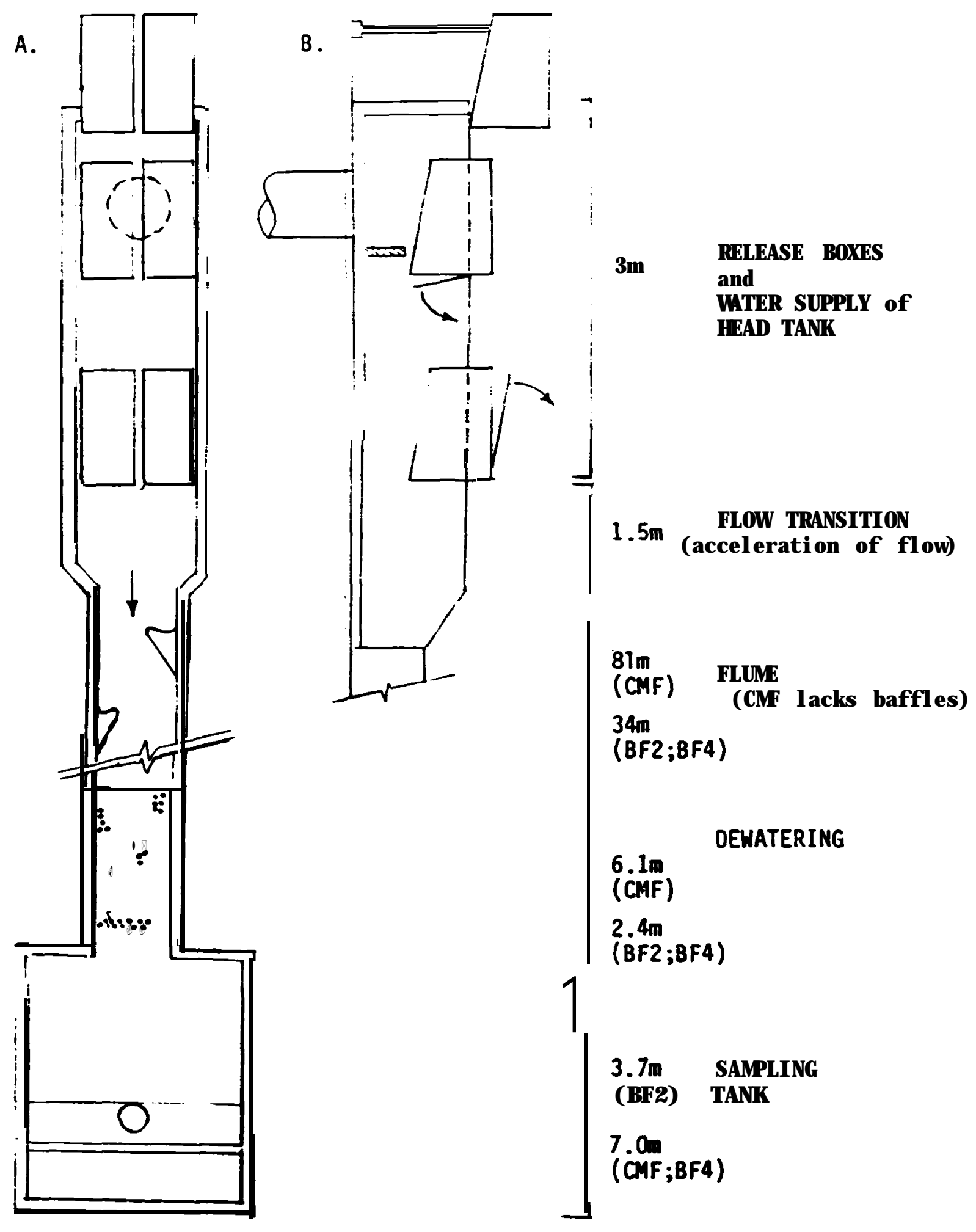

Fig. 1 Schenatic (A, top vi ew B, si de vi ew) of the three test fl unes: corrugated metal fI ume(CMF), baffled fI umes $1.22 \mathrm{~m}$ wi de (BF4) and $0.61 \mathrm{~m}$ wi de (3F2). 
Snol ts that had entered the gatewel Is during the day were fi rst removed by repeating di pping, so that onl y snol ts that had recently entered were used for our tests. Fi sh were anesthetized pri or to handling.

We I oaded 20-22 smol ts i nto each of 18 aerated 19 L buckets. Lots of $\mathrm{fi}$ ve snol ts were added to the buckets in rotating sequence to avoi d bi as in sel ection or treat ment of fish. The smol ts were transported by pi ckup truck to the fi sh passage facility and l oaded into hol ding tanks at the head of each fI une.

Nightti me tests were perforned about 24 hours after I oadi ng of $f$ i sh into the hol ding tanks. Dayti me tests were performed the foll owing day, about 38-40 hours after I oading. For dayti ne tests the perforated metal covers over the fI umes were ei ther covered with opaque bl ack pl asti $c$ (compl et el y darkened) or were uncovered (parti al ly darkened). The testi ng sequence of the tuo I i ght condi ti ons al ternated, with the parti al I y darkened condi ti on first in trial s 1, 3, 5, and 7. The order i $\mathrm{n}$ whi ch fl unes were tested was sel ected at random Dayti me tests were i ni ti ated bet ueen 1000 and $1700 \mathrm{~h}$ and ni ghtti me tests bet ween 2130 and $0100 \mathrm{~h}$.

Tests were i nitiated by netting a basel i ne sample of fi sh ( $N=20)$ from a hol di ng tank. After the fi sh were anesthetized i $\mathbf{n} 75 \mathrm{ng} / \mathrm{L}$ of Tri cai ne Methane Sul fonate ( MS- 222) and exami ned for descal ing, the caudal peduncl e was severed and bl ood was col l ected i $n$ hepari ni zed capi I lary tubes. Pl asma was separated by centrifuguti on and frozen on dry i ce i n mi crocent ri f uge tubes.

A second tank was randon y sel ected and the fi sh rel eased i nto the fl une. After the fi sh were rel eased, the crouder screen bel ow the hol di ng tanks was pul led downstream to force them to swi m downst ream Fl unes were dewatered $20 \mathrm{~min}$ after rel ease of fish into the BF2 and BF4 and $10 \mathrm{~m} \mathrm{n}$ after rel ease into the CMF. Any fish renaining in the fl unes af ter this ti me were counted and rel eased i nto the Snake Ri ver. Fi sh that had passed through the fl une were sampl ed from the tank at the base of each $f($ ume one hour after rel ease in the manner described for basel ine samples.

\section{Determi nation of PI asma Corti sol and Lactate Concent rations}

PI asma speci mens were thaued, vortexed and pool ed by conbi ni ng $\mathbf{1 0 0}$ uL of pl asma fromeach of four di fferent tubes to obtai $n 5$ subsampl es for each 20-fi sh sample. If samples consi sted of less than 15 plasma speci mens, each speci men was anal yzed i ndi vi dual l y. Cort i sol concentrati ons i $\mathrm{n}$ pl asma vere det ermi ned by a radi oi munoassay nodi $\mathrm{f} i \mathrm{ed}$ from Foster and Dunn (1974) by Reddi ng et al. (1984). I nter-assay and intra-assay coeffici ents of variation were $24 \%$ and $12 \%$

PI asm I actate concentrations uere determined by a spectrophotomet ri c method based on the conversi on of I actate to pyruvate and NAOH in the presence of excess NAO and I act ate dehydrogenase ( Si gna di agnosti c ki t 826- UN). A standard curve was prepared for each run. 


\section{Criteri a for Descal ing}

To esti mate the extent of descal ing, we vi sual I y esti mated the percent of descal ed area wi thi $n$ each of 10 body zones as recomended by Basham et al. ( 1982). The I eft and ri ght si des were di vi ded i nto fi ve zones: 1) caudal fi n to anteri or end of adi pose fi $n, 2$ ) ant eri or end of adi pose fin to posteri or end of dorsal $f i n$, 3) posteri or end of dorsal $f i n$ to anterior end of dorsal fin, 4) anterior end of dorsal fin to tip of the pectoral fin when it is fol ded agai nst the body, and 5) tip of pectoral fi $n$ to anterior insertion of pectoral fin. The same person generally recorded descal ing dat a for each test, so that compari sons of basel i ne and post passage sampl es as wel $\mathrm{I}$ as comparisons bet ween fl unes were unbi ased. formul a:

The percent of body surface descal ed per $f i$ sh was cal cul ated by the

$$
D=((L 1 * 0.5)+L 2+L 3+L 4+L 5+(R 1 * 0.5)+R 2+R 3+R 4+R 5) / 9
$$

in which L2 represents the percent of descal ed area in zone 2 of the I eft si de. Note that zone 1 (caudal peduncle area) of each si de was wei ghted by a factor of 0.5 due to the smaller si ze of the zone rel ati ve to the others. The nean descal ing rate was cal cul ated for each sample of 20 fish.

A second criterion for descal ing was the percent of fish i $n$ a sample with more than $5 \%$ descal ing in any one or nore of the 10 body zones.

\section{Anal ysi s of Corti sol and Descal i na Data}

Basel i ne corti sol data were tested by anal ysi s of vari ance (ANOVA, randomized bl ock fact orial desi gn) at the $5 \%$ probability level for effects of tank I ocation ( $i$.e., at head of one of three test fl unes) and I i ght condi $t i$ on. The ef $f$ ect of I $i$ ght condi $t i$ on was si gni ficant, so nean basel i ne corti sol concentrati ons were cal cul at ed separatel y for ni ght ti ne and dayti me tests and subtracted from post passage corti sol concent rati ons to esti mate net changes in pl asma cortisol resulting from fl une passage. These data were anal yzed by ANOVA for effects of $f I$ une desi gn and I i ght condi ti on, fol l oned by pai $r$-wi se compari son of i ndi vi dual means (Tukey's HSO test) if treatment ef fects were si gni fi cant ( $P<0, \infty)$. ANOVA resul ts uere al nost i denti cal wi th l og-transf orned and unt ransf or med corti sol data, so results obtai ned with untransformed data are reported.

Oescal ing data were anal yzed by ANOVA, fol l owing the procedures described for anal ysi s of corti sol data. Oescal ing percentages were transf ormed to arctangents bef ore anal ysi s. 


\section{Behavi or of Adul $\mathbf{t}$ Chi nook Sal non i n Fl unes}

Adul t chi nook sal non ( $685 \mathrm{~mm}$ to $850 \mathrm{~mm}$ l ength range) were renoved from the adul t trap at the dam anesthetized, and transported to a hol di ng tank at the head of each flume. A smal I bal I oon was attached by a hook and nonofil anent I i ne to the dorsal fin to facilitate observation af ter rel easi ng the fish i nto the fI ume. In addition, 20 chi nook snol ts were I oaded i nto a hol di ng tank of each fl une in tri al s 1 and 2; 20 steel head snol ts were used for trial 3.

Tri al s 1 and 2 were conducted on Apri I 29, 1987, and trial 3 on Myy 20. For each tri al, adul $t$ sal mon were rel eased i nt o the fl unes fi ve $m \mathbf{n}$ bef ore the smolts were rel eased. After $20 \mathrm{~min}$ the fl ume was dewatered and the number of snol ts remai ni ng in the fl une counted. In trial 3, the fl ume was shut down after $10 \mathrm{~min}$, si nce pri or experience shoued that al I the smol ts had passed through the flume after $20 \mathrm{~min}$. After fl une passage, the adults were netted out of the sample tank into a pl astic gar bage can cont ai ni ng a $50-75 \mathrm{ng} / \mathrm{L}$ sol ut i on of $\mathrm{MS} 222$ anest het $\mathrm{i}$ c, I oaded into the fi sh transport truck (contai ni ng a $25 \mathrm{mg} / \mathrm{L}$ MS222 sol uti on), and rel eased at the boat I aunch above the dam. The adul ts recovered in a matter of mi nutes, and conti nued thei $r$ upstream migation. A I trial s were conducted during the day with partial I y darkened fI umes.

\section{Passaqe of Debris Through Fl umes}

Whter-soaked debris was cast into each fl une pi ece by pi ece. The water was I eft on until al I debris had ei ther passed or l odged. Once the fl une was dewatered, the number and size of the debris that had lodged in the fl unes were recorded. The sane debris was used in tests with al I fl unes.

Debri s used for the first test (May 20) had passed through the orifices at Little Goose Dam and was kept waterlogged until testing. Bel ow nor nal water fl ow greatl y reduced the anount of debris reaching Little Goose Dam so the reserved debris was not representative of a typi cal year.

To rectify the probl em the test was repeated on Myy 27, 1987, using the debri s collected at Little coose pl us an addi ti onal 15-20 pi eces of woody debris chosen fromt he Lover Grani te Dam debris pi le by Sarah Villis, fi shery bi ol ogist at Lower Granite, who had worked at the Little coose facility in previ ous years. The debris filled three 50-gall on garbage cans. 


\section{Di el Vari ation i n Basel i ne Corti sol Concentrati ons and Effects of}

\section{Li aht I ntensi ty}

\section{Baseline Cortisol Concentrations in Chinook Salmon}

The objectives of this test were to determine if pl asma cortisol concentrati ons i n chi nook sal mon snol ts vari ed si gni fi cantl y bet ween day and ni ght, and to determine the effects of constant darkness upon any day to ni ght vari ation.

Tuel ve al umi num tanks i denti cal to the hol di ng tanks at the head of each fl une were stocked with 20 snol ts each. Si $x$ of the tanks were covered with opaque I i ds which reduced the i nteri or I i ght intensity to $<0.1$ I ux; the renai ning si $x$ tanks were covered with a layer of transl ucent pl asti c whi ch reduced the i ntensi ty of i nci dent I i ght onl y sl i ght l y ( $m$ dday naxi mum 3800 I ux). The overfI ow screens of al I tanks were covered with duct tape. The fi sh were al I owed to accl i mate to the tanks for 24 hours bef ore the first sample was taken. The fish uere not fed.

Subsequentl y, one uncovered and one covered tank were sampl ed each day $(1100 \mathrm{~h})$ and each ni ght ( $2300 \mathrm{~h})$ for three days and ni ghts. Three tríal s of the test were conduct ed (April 13, 17, and 29).

The resul ts were stati sti cal I y anal yzed by ANOVA ( randomized bl ock factorial desi gn) comparing corti sol concent rations bet ween fi sh hel d i n covered and uncovered tanks. Day versus ni ght differences were si mi arly tested (ANOVA) by comparing the overal I nean of al I si $x$ ni ght sampl es ( covered and uncovered) with the mean of the si $x$ day sampl es.

\section{Cortisol Concentrations in Chinook Salmon and Steel head Trout Held in} Raceways

The objectives of this test were to determine if pl asma cortisol concentrati ons i $\mathbf{n}$ chi nook sal mon and steel head trout hel $\mathbf{d}$ i $\mathbf{n}$ raceways vari ed si gni fi cantl y bet ueen day and ni ght, and to determine the ef fects of raceway darkening upon any day to ni ght variation.

A barrier of plastic netting with a wood frame was placed into each of t no raceways, 9.1 $\mathrm{m}$ from the i nfl ow One raceway (no. 7 for trial 1 , no. 8 for trial 2) was covered for its enti re length ( $27 \mathrm{~m}$ ) with a double I ayer of bl ack pol yet hel ene, wei ght ed down on the out si de wal I s of the raceway with nood pl anks. Li ght i ntensiti es bel ow the cover were 1. 0-4.0 I ux on a sunny day at $1030 \mathrm{~h}$.

The $9.1 \mathrm{msecti}$ ons of the raceways encl osed by the mesh barriers were I oaded with fi sh that had entered the snol t col l ection system and passed through the bypass pi pe and debris separator. Tri als with chi nook sal non were conducted when the percent of chi nook sal mon snol ts was hi gh (93-95\% and trial s wi th steel head were conducted when the percentage of st eel head was hi gh $(82-92 \%$. 
After a 4 to 5 h I oading peri od $(0900-1400$ h), each raceway cont ai ned approxi matel y 5000 snol ts of both speci es. Popul ation esti mates were based on a sampl e of $\mathrm{fi}$ sh di verted through el ectronagnet i c fi sh counters for 3-5 $\mathrm{min}$ of every, hour (9-12\% subsampl e). The resul ti ng densities were 27-29 smolts/m-1 nitests with chi nook sal mon and 24- 35 snol ts/m in tests with steel head. Fl ous were mai nt ai ned at 3400-3800 $\mathrm{L} / \mathrm{min}$. The bi onass of chi nook snol ts per raceway vari ed bet ween 142-176 $\mathrm{kg}$ (8. 3-10.3 g/ L) and steel head vari ed bet ween 343-372 kg (20. 1- 21. $8 \mathrm{~g} / \mathrm{L}$ ).

Begi nni ng the day that fi sh were I oaded, bl ood sampl es were taken from 20 smol ts fromeach raceway over the course of t no days and ni ghts at 1600, 2300, 0400, and $1100 \mathrm{~h}$. The I ast sampl e was col lect ed at 0800 rather than 1100 hours because the smol ts had to be I oaded i nto barges by $0900 \mathrm{~h}$.

Two trial s of the test were conducted. Fi sh were capt ured by "I ift" nets ( $61 \mathrm{~cm}$ or $47 \mathrm{~cm}$ square) that were haul ed up qui ckl y from the bott om by ropes pulled by two persons on either si de of the raceway. The net was I ef $t$ I yi ng on the bott om of the raceway between sampl es. Si nce fi sh i n the uncovered raceway could see us, we al ways sampled it first to avoid possible el evation of cortisol concentrations due to fright.

Bl ood sampl es were taken as descri bed for the fl ume compari son tests. For stati sti cal anal ysi s, day versus ni ght di fferences vere tested (ANOVA) by comparing the overal l mean of the $8 \mathrm{ni}$ ght sampl es (covered and uncovered) with the mean of the 8 day sampl es. A pai red T-test was used to compare corresponding covered and uncovered samples.

\section{Effect of Reduced Light Intensity on Cortisol Concentrations in Chinook Salmon and Steel head Trout}

The obj ecti ve of this test was to determine the rel ationshi $p$ bet ween I i ght i ntensi ty and pl asma corti sol concentrations i $n$ chi nook sal non and steel head trout snol ts held in tanks.

The 12 168- $L$ al umi num tanks previ ousl y descri bed were I oaded at ni ght with 20 snolts each. Each of the twel ve tanks was randonly assi gned one of four I evel s of I i ght i ntensi ty, whi ch were attai ned by coveri ng the tanks with a si ngl e I ayer of transl ucent white plastic, with one or t wo I ayers of sem-opaque bl ack pl astic (1.2 mil), or with an opaque $f i$ bergl ass I id. The overf I ow screens of al I tanks were covered with duct tape, l eaving an overlap at the bottom for the water overfl ow M dday I ight intensities at the surface of the water in the tanks were 3800, 470, 4, and $<0.1$ I ux.

Fi sh were sampl ed fromal I tanks at 1000-1630 h, 32- 36 hours after l oadi ng. Tanks were sampl ed i n random order. Two tri al s were conducted usi ng chi nook and tuo usi ng steel head smolts. For statistical anal ysis an ANOVA, randomized bl ock factori al desi gn, was used. 


\section{Cortisol Concentrations in Isolated Chi nook Salmon}

The obj ecti ve was to determi ne whet her diel changes in agoni stic behavi or might be responsi bl e for di el cycles in corti sol concentrations i n chi nook sal non snolts. The approach was to eval uate di fferences i $n$ cortisol concentrations between chi nook sal mon snol ts that were physical ly but not vi sual I y i sol at ed from other fi sh and snol ts that were both physi cally and vi sual ly i sol ated. We assumed that any agoni stic i nt eracti ons noul d be vi sual ly medi ated.

The 12 tanks previ ousl y descri bed were nodi $\mathrm{f} i$ ed by subdi vi di ng each tank i nto four compartments of equal vol une. In the first two trials the di vi ders were plastic netting supported by a uood frane, permitting vi sual contact bet ween fish in uncovered tanks. In the thi rd and fourth trial s, di vi ders were covered with opaque bl ack pol yethel ene, thus physi cal ly and vi sual I y i sol ating each snolt. Si $x$ tanks nere covered with opaque covers and si $x$ with transl ucent covers as previ ously described.

Snol ts were sampl ed from three covered and three uncovered tanks at ni ght (2230-0130 h), 24 hours after I oadi ng one fi sh per compartment ( 4 per tank). Snol ts i n the remai ni ng si $x$ tanks were sampl ed the fol I ow ing day (1100-1300 h). PI asma speci mens uere taken as previ ousl y described, but each speci nen was i ndi vi dual ly anal yzed and not pool ed.

For st at i sti cal anal ysi s, a randomi zed bl ock desi gn fi rst eval uat ed di fferences in cortisol concentrations bet ween the four compartments wi thi $n$ a tank. The differences were i nsi gnifi cant i $n$ both covered and uncovered tanks, so an average of the four samples withi $n$ a tank was used for subsequent ANOVA. A randomized bl ock desi gn was used to test di f ferences bet ween covered and uncovered tanks, ni ght versus day, and bet ween corti sol concentrations i $n$ tanks using the two different types of di vi ders. Dat a from covered and uncovered tanks were anal yzed separatel y and together to test the two types of i sol at $i$ on. 


\section{RESULTS}

\section{PI asna Corti sol Concentrations Before and After Fl une Passaqe}

\section{Chi nook Salmon}

Hol di ng tank I ocati on di d not have a si gni $\mathrm{f} i$ cant ef fect on basel i ne corti sol concentrati ons in chi nook sal mon snol ts, but concentrations i n ni ght ti ne sampl es were si gni fi cantl y l ower than i n dayt i me sampl es ( $P \varangle 0.0001)$. Therefore, an average ni ghtti me basel i ne corti sol concent rati on (109. $0 \mathrm{ng} / \mathrm{mL}$ ) was subt racted from ni ghtti me post passage concentrati ons and an average dayti me basel i ne average (148. $0 \mathrm{ng} / \mathrm{mL}$ ) was subt racted from dayti ne (compl etel y darkened and partial I y darkened) post passage concentrati ons to det ermine net changes in corti sol fol l owing fl une passage ( Table 1 ).

Table 1. Mean concent rati ons ( $\pm \mathrm{SE}, \mathrm{N}=7$ trial s) of pl asme corti sol ( $\mathrm{ng} / \mathrm{mL}$ ) i n chi nook sal non snol ts bef ore (BL) and after (PP) passage through three f I unes under three I i ght condi ti ons.

\begin{tabular}{|c|c|c|c|c|}
\hline \multirow[b]{2}{*}{ FI ume } & & \multicolumn{3}{|c|}{ Li ght Condi ti on } \\
\hline & & N ght & $\begin{array}{l}\text { Parti al I y } \\
\text { Darkened }\end{array}$ & $\begin{array}{c}\text { Compl et el y } \\
\text { Darkened }\end{array}$ \\
\hline BF2 & $\begin{array}{l}\text { BL } \\
P P \\
P P-X B L^{a}\end{array}$ & $\begin{array}{r}136.8+16.4 \\
144.6+11.9 \\
35.6\end{array}$ & $\begin{array}{r}139.7+12.9 \\
141.0+12.7 \\
-7.0\end{array}$ & $\begin{array}{l}135.8+9.2 \\
112.3 \pm 14.9 \\
-35.7\end{array}$ \\
\hline$\overline{\mathrm{BF} 4}$ & $\begin{array}{l}\text { BL } \\
\text { PP } \\
\text { PP- XBL }\end{array}$ & $\begin{array}{r}92.0 \pm 16.8 \\
139.6 \pm 15.0 \\
30.6\end{array}$ & $\begin{array}{l}162.2 \pm 10.2 \\
117.4 \pm 16.4 \\
-30.6\end{array}$ & $\begin{array}{l}161.0 \pm 16.3 \\
124.2 \pm 15.0 \\
-23.8\end{array}$ \\
\hline$\overline{\text { CMF }}$ & $\begin{array}{l}\text { PP } \\
P P-X B L\end{array}$ & $\begin{array}{r}\mathbf{9 8 . 2} \pm \mathbf{1 5 . 5} \\
145.536 .5 \pm 19.5\end{array}$ & $\begin{array}{l}\mathbf{1 4 3 . 7} \pm \mathbf{1 5 . 6} \\
141.5-6.5 \pm \mathbf{1 0 . 7}\end{array}$ & $\begin{array}{l}\mathbf{1 4 5 . 5} \pm \mathbf{8 . 7} \\
101.047 .0 \pm 10.4\end{array}$ \\
\hline
\end{tabular}

a Postpassage corti sol concentrati on mus an average ni ght ti me (109.0 $\mathrm{ng} / \mathrm{mL}$ ) or dayti me ( $148.0 \mathrm{ng} / \mathrm{mL}$ ) basel i ne concent rati on.

After the smolts had experi enced rel ease from the hol di ng tank, a t umul tuous ri de through the fi une, and an hour in the sampl ing tank, one noul d expect cortisol concentrations to rise above those of the basel i ne sampl es. Neverthel ess, for chi nook sal non there was no si gni i cant di ff erence bet ueen basel $i$ ne and postpassage concentrations when data for al I I i ght conditions were tested. When data for the three I i ght condi $t i$ ons were tested separatel $y$, post passage corti sol concentrations were si gni fi cantl y l ower than basel i ne concent rati ons i n fi sh passing through fl unes in dayti me tests (parti al ly and compl etel y darkened). We 
attribute this decli ne in corti sol concentrations to the combi ned effects of sonewhat stressful condi ti ons in the hol ding tanks, rel ativel y unstressf ul condi ti ons in the recei vi ng tanks, and the absence of a strong stress response to fl une passage. Differences between basel i ne and post passage cortisol concentrations were i nsigni ficant in ni ght ti ne tests.

Fl ume desi gn di d not have a si gni fi cant ef fect on net changes i $n$ corti sol concent ration ( $P=0,9)$ in tests wi th chi nook sal mon. Anal ysi s of dat a for dayti me tests al one i ndi cated that corti sol concentrations for fi sh passi ng through covered fI unes were si gni fi cantl y I ower ( $P=0, \infty)$ than for fish passing through partially covered fl unes.

\section{St eel head Tr out}

Hol di ng tank I ocati on di d not have a si gni fi cant effect on basel i ne corti sol concentrati ons, but concent rati ons i n ni ghtti me sampl es uere si gni fi cantly l ower than i n dayti ne sampl es $(P=0.002)$. Ther ef ore, an average ni ght ti me basel i ne corti sol concent rati on ( $174 \mathrm{ng} / \mathrm{mL}$ ) was subt racted from ni ght $t i$ me post passage concentrati ons and an average dayt i ne basel i ne concentrati on ( $212 \mathrm{ng} / \mathrm{mL}$ ) was subt racted from dayti ne (darkened and partially darkened) postpassage concentrations to determine net changes in cortisol fol I owing fl une passage (Table 2).

Tabl e 2. Mean concent rati ons ( \pm SE, $N=7$ trial s) of pl asma corti sol ( $\mathrm{ng} / \mathrm{mL}$ ) in steel head trout snolts before (BL) and after (PP) passage through three f I umes under three I $\mathrm{i}$ ght condi $t i$ ons.

\begin{tabular}{|c|c|c|c|c|}
\hline \multirow[b]{2}{*}{ Fl une } & & \multicolumn{3}{|c|}{ Li qht Condi ti on } \\
\hline & & N ght & $\begin{array}{l}\text { Parti al I y } \\
\text { Darkened }\end{array}$ & $\begin{array}{c}\text { Compl et el y } \\
\text { Darkened }\end{array}$ \\
\hline BF2 & $\begin{array}{l}\mathrm{BL} \\
\mathrm{PP}-X \mathrm{XL}^{\mathrm{a}}\end{array}$ & $\begin{array}{l}159.5 \pm 12.2 \\
288.8 \pm 26.2\end{array}$ & $\begin{array}{l}227.9 \pm 16.8 \\
297.0 \pm 16.1\end{array}$ & $\begin{array}{l}210.3+22.5 \\
310.4+20.6\end{array}$ \\
\hline BF4 & $\begin{array}{l}\text { BL } \\
\text { PP } \\
\text { PP- XBL }\end{array}$ & $\begin{array}{r}188.3 \pm 16.1 \\
254.0 \pm 23.1 \\
8.0\end{array}$ & $\begin{array}{r}196.4 \pm 21.0 \\
294.5 \pm 24.8 \\
82.5\end{array}$ & $\begin{array}{r}184.6 \pm 16.7 \\
270.6 \pm 14.7 \\
58.6\end{array}$ \\
\hline CMF & $\begin{array}{l}P P \\
P P-X B L\end{array}$ & $\begin{array}{r}\mathbf{1 7 4 .} \mathbf{8} \mathbf{+ 1 2 . 9} \\
248.274 .2 \pm \mathbf{2 4 . 6}\end{array}$ & $\begin{array}{l}259.0 \pm \mathbf{1 3} .0 \\
231.647 .0 \pm \mathbf{1 3} .0\end{array}$ & $\begin{array}{l}215.8 \pm 19.3 \\
260.748 .7 \pm 13.8\end{array}$ \\
\hline
\end{tabular}

a Post passage corti sol concentrati on mi nus an average ni ghtti me ( 174 $\mathrm{ng} / \mathrm{mL}$ ) or dayti me ( $212 \mathrm{ng} / \mathrm{hL}$ ) basel i ne concent rati on. 
Post passage concentrati ons were si gni fi cantl y hi gher than basel i ne concentrations $(P<0.0001)$, wi th net i ncreases rangi ng up to $115 \mathrm{ng} / \mathrm{mL}$. The three fl unes differed ( $P \varangle 0,000$ ) when al I three Ii ght condi ti ons were anal yzed together. Each of the three fl umes differed si gnifi cant l y ( $P<0.05$; Tukey mul ti pl e compari son procedure) from the ot her $t$ wo. The BF2 had the hi ghest average corti sol i ncrease (101. $4 \mathrm{ng} / \mathrm{mL})$, fol I owed by the BF4 (73. $7 \mathrm{ng} / \mathrm{mL}$ ) and the CMF (47.5 $\mathrm{ng} / \mathrm{mL})$.

Night ti me corti sol i ncreases i n corti sol concentrati ons were hi gher ( $P=0,02)$ than dayti ne i ncreases in snol ts passing through parti al I y and compl et el y darkened fl unes, but absol ute post passage concentrations di d not differ si gnifi cantly ( $P=0.13)$ for ni ght ti me and dayt i me condi ti ons. When dat a f or parti al l y and compl et el y darkened dayt i me tests were anal yzed apart from the data for ni ghtti me tests, no di fferences vere apparent.

\section{Rate of Passage of Snol ts through Fl unes}

Some smol ts of ten remai ned i $\mathrm{n}$ the $\mathrm{fl}$ unes when they were dewat ered $\mathbf{2 0}$ mi (BF2, BF4) or $10 \mathrm{~min}$ (CMF) after snol ts were rel eased (Table 3). These fi sh di $d$ not reach the sample tank or reached it and suam back upstream Lower vel ociti es in the baffled fl unes al l owed nore snol ts to stay in these fl unes; fi sh coul d not swi m upstream agai nst the hi gher vel ocities in the CMF.

Tabl e 3. Average nunber ( $\mathrm{N}=7$ tri al s) of chi nook sal non and steel head trout snol ts remaining in the three fl unes under three I i ght condi ti ons ( 22 fi sh were rel eased in each trial).

\begin{tabular}{cccc}
\hline Fl une & Ni ght & Covered & $\begin{array}{c}\text { Parti al I y } \\
\text { Covered }\end{array}$ \\
\hline $\begin{array}{c}\text { chi nook } \\
\text { BF2 }\end{array}$ & 3 & 1 & \\
BF4 & 0 & $\mathbf{0}$ & 2 \\
CMF & $\mathbf{0}$ & 1 & $\mathbf{0}$ \\
st eel head & & & \\
BF2 & 4 & 4 & 6 \\
BF4 & 7 & 7 & 9 \\
CMF & $\mathbf{0}$ & 1 & 1 \\
\hline
\end{tabular}

The number of chi nook snol ts remai ni ng in the fl umes vari ed from 0 to $11(0.50 \%$ of $\mathrm{fi}$ sh rel eased). The number of st eel head vari ed from 0 to $18(0.82 \%$ of $\mathrm{fi}$ sh rel eased). Mre steel head than chi nook sal mon were found in al I the fI umes after dewatering, probably because the I arger 
st eel head snol ts (average I engt $h=207 \mathrm{~mm}$ vs. $144 \mathrm{~mm}$ for chi nook sal mon) uere abl e to fi ght the current I ong enough to find shel teri ng eddi es behi nd the wi ndow ports of the CMF or the baffles of the other two flunes.

As expected, ANOVA and subsequent compari son of means showed that si gni f i cant l y f ewer chi nook $(P<0.025)$ and st eel head $(P<0,003)$ remai ned i $n$ the CMF compared to the baffled fl unes. Light condition di d not have a si gni fi cant ef fect.

\section{PI asm Lactate Concentrati ons Bef ore and After Fl une Passaae}

Mean basel i ne pl asm I actate concentrati ons ( $N=20)$ i $n$ chi nook sal mon ranged from 1 to $2 \mathrm{mMl} / \mathrm{L}$ and post passage concent rations from 2.1 to 3.8 $\mathrm{mMbl} / \mathrm{L}$ ( Tabl e 4). Basel i ne concent rati ons in st eel head trout ranged from 2.1 to $6.5 \mathrm{mMd} / \mathrm{L}$ and post passage concentrati ons from 2. 6 to $5.8 \mathrm{mMl} / \mathrm{L}$. $\mathrm{Nb}$ differences uere attributable to fl une design or I i ght condi ti on. Post passage I act ate concentrati ons i $n$ both speci es were general l y equal to or I ower than I actate concent rati ons neasured i n chi nook sal mon sampl ed from gat ewel Is at Lower Grani te Dam i n 1982 (Congl et on et al. 1983).

Table 4. PI asma I actate concentrati ons (mMol/L) i n chi nook sal mon (Apri I 6-9 tests) and steel head trout (My 2-3 tests) snol ts bef ore (basel i ne, $B L$ ) and one hour after passage (postpassage, PP) through three fl unes. Dayti me tests were perforned with fl unes partially (PD) or compl etel y (CD) darkened.

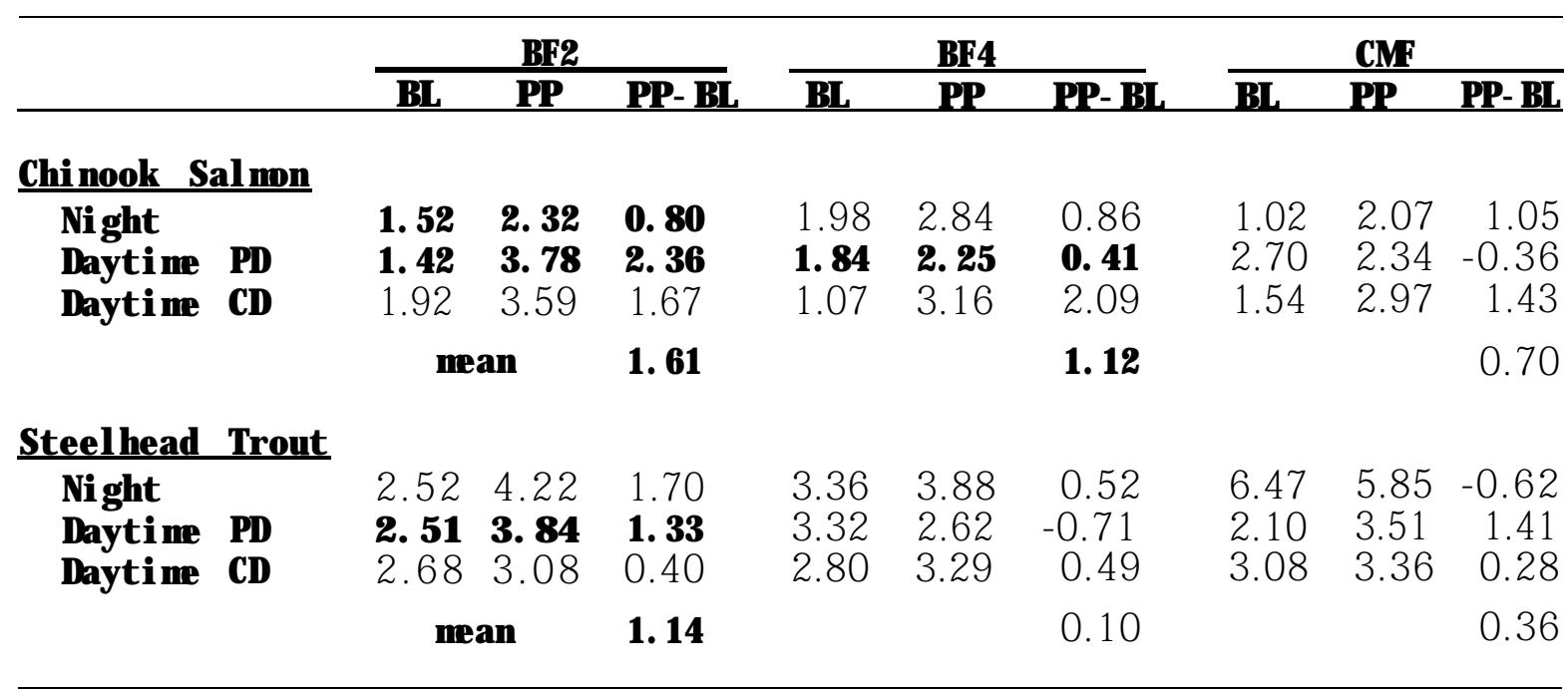




\section{Descal i nq of Snol ts i $n$ Fl unes}

Chi nook Salmon

There was no si gni fi cant di fference bet ween basel i ne and post passage sampl es in the percent of chi nook sal mon with descal ing or in descal ing of fish that passed through the three flunes (Table 5).

Tabl e 5. Average ( $\pm \mathrm{SE}, \mathrm{N}=7$ trial s) percent of chi nook snol ts wi th more than $5 \%$ descal ing in any one of ten body zones bef ore (BL) and after (PP) passage through three fl une desi gns under three I i ght condi ti ons.

\begin{tabular}{llrrrr}
\hline Fl une & & N ght & \multicolumn{2}{c}{$\begin{array}{c}\text { Parti al I y } \\
\text { Cover ed }\end{array}$} & Covered \\
\hline BF- 2 & BL & $8.6 \pm 1.9$ & $23.0 \pm 5.8$ & $23.6 \pm 2.3$ \\
& PP & $25.0 \pm 4.9$ & 31.4 & \pm 4.3 & $17.8 \pm 2.6$ \\
\hline BF- 4 & BL & $22.3 \pm 4.8$ & 23.1 & \pm 3.4 & $28.0 \pm 4.6$ \\
& PP & $16.1 \pm 2.7$ & $30.0 \pm 4.6$ & $18.6 \pm 2.5$ \\
\hline CMF & BL & $21.1 \pm 2.9$ & $19.3 \pm 3.6$ & $28.1 \pm 4.0$ \\
& PP & $20.4 \pm 3.2$ & $24.3 \pm 3.0$ & $24.1 \pm 5.4$ \\
\hline
\end{tabular}

The average $(\mathrm{N}=20)$ percent of body surface descal ed ranged from 0 to 14 percent i n i ndi vi dual sampl es (Table 6). There were no si gni fi cant di f f er ences bet ween $f$ I unes, bet ween the three I i ght condi ti ons, or bet ueen basel i ne and post passage sampl es.

Table 6. Average $( \pm S E, N 7$ ) percent of body surface descal ed per chi nook sal mon snol $t$ bef ore (BL) and after (PP) passage through three different fl une desi gns under three I i ght condi ti ons.

\begin{tabular}{|c|c|c|c|c|}
\hline \multicolumn{2}{|c|}{ Fl une } & \multirow{2}{*}{$\begin{array}{l}N \text { ght } \\
6.1 \pm 1.9 \\
5.6 \pm 2.3\end{array}$} & \multirow{2}{*}{$\begin{array}{c}\text { Parti al I y Covered } \\
2.7 \pm 0.7 \\
5.1 \pm 1.3\end{array}$} & \multirow{2}{*}{$\begin{array}{l}\text { Covered } \\
4.3 \pm 1.4 \\
4.9 \pm 1.0\end{array}$} \\
\hline BF2 & $\begin{array}{l}\mathrm{BL} \\
\mathrm{PP}\end{array}$ & & & \\
\hline BF4 & $\begin{array}{l}\text { BL } \\
\text { PP }\end{array}$ & $\begin{array}{l}3.2 \pm 0.8 \\
5.9 \pm 1.3\end{array}$ & $\begin{array}{l}3.6 \pm 1.3 \\
5.7 \pm 1.0\end{array}$ & $\begin{array}{l}4.5 \pm 0.8 \\
7.3 \pm 2.2\end{array}$ \\
\hline CMF & $\begin{array}{l}\text { BL } \\
\text { PP }\end{array}$ & $\begin{array}{l}3.9 \pm 1.0 \\
3.7 \pm 0.9\end{array}$ & $\begin{array}{l}2.6 \pm 0.7 \\
3.5 \pm 0.7\end{array}$ & $\begin{array}{l}4.3 \pm 1.0 \\
2.7 \pm 0.4\end{array}$ \\
\hline
\end{tabular}


St eel head Tr out

There was no si gni fi cant di fference bet ween basel i ne and post passage sampl es i $n$ the percent of steel head trout with descal ing or in descal ing of fish that passed through the three fl unes (Table 7).

Tabl e 7. Average percent $( \pm S E, N-7)$ of steel head trout snol ts with more than $5 \%$ descal ing in any one of ten body zones bef ore (BL) and after (PP) passage through three di fferent fI une desi gns under three li ght conditions.

\begin{tabular}{llccc}
\hline Fl ume & & N ght & Parti al I y Covered & Covered \\
\hline BF2 & BL & $46 \pm 12$ & $57 \pm 8$ & $60 \pm 10$ \\
& PP & $50 \pm 10$ & $52 \pm 10$ & $60 \pm 9$ \\
\hline BF4 & BL & $47 \pm 11$ & $53 \pm 12$ & $55 \pm 6$ \\
& PP & $39 \pm 11$ & $62 \pm 8$ & $65 \pm 11$ \\
\hline CMF & BL & $53 \pm 11$ & $45 \pm 12$ & $48 \pm 11$ \\
& PP & $47 \pm 10$ & $58 \pm 8$ & $61 \pm 8$ \\
\hline
\end{tabular}

The average ( $N=20)$ percent of body surface descal ed ranged from 0 to 12 percent i n i ndi vi dual samples (data not shown). Val ues were si milar to those for the chi nook samples. There were no si gni fi cant di fferences due to fl une desi gn or I i ght condition, or bet ween basel i ne and post passage sampl es.

Behavi or of Adult Chi nook Sal mon in Fl umes

In the first trial in the BF4, the adult chi nook sal non travel led dounstream frombehi nd one baffle to behi nd the next until it reached the screen at the I ower end $107 \mathrm{~s}$ after rel ease. Sonewhere bet ueen the screen and the sample tank at the base of the fI une the I i ne to the attached bal I oon broke, so that the I ocation of the fi sh could no I onger be determined. When the fl une was dewatered, the adul $t$ was above the screen, al though al I the snol ts had passed. Apparently, the adul t sal mon reached the sample tank and suam back upstream Thi s was the onl y case i $n$ which an adul $t$ renai ned i $n$ the fl une; al I others passed i $n$ a few mi nutes ( Table 8). 
Tabl e 8. Passage ti me (s) of adul t chi nook sal mon through three fI unes.

\begin{tabular}{cccl}
\hline & \multicolumn{3}{c}{ Fl une } \\
\cline { 2 - 4 } Tri al & BF- 2 & BF- 4 & CMF \\
\hline $\mathbf{1}$ & 110 & $\mathbf{1 0 7}$ & a \\
$\mathbf{2}$ & $\mathbf{1 4 0}$ & $\mathbf{3 0 0 - 1 2 0 0 ^ { b }}$ & 37 \\
3 & 91 & 97 & 33 \\
\hline
\end{tabular}

a $\mathrm{Nb}$ ti me recorded due to escape of adul $t$ fish from hol di ng tank.

b The ball oon I i ne broke after $5 \mathrm{~min}$ while the fi sh was still in the fl une, but the adul $t$ had passed after $20 \mathrm{~min}$.

A I chi nook sal mon smol ts passed through the fl umes wi thi $n$ twenty mi n, but 17 and 15 steel head smol ts were still in the BF4 and BF2 after 10 min (trial 3). Si nce the adul ts had passed through the fl unes before the st eel head smol ts were even rel eased, smol t passage was not affected by the presence of an adul $t$.

\section{Passage of Debris Through Fl unes}

A I debris passed through the CMF without I odging in both trials. In the first trial with the BF4, a Iog jam forned at the thi rd baffle in whi ch there were 5 sti cks rangi ng from $1 \mathrm{ml}$ ong and $3 \mathrm{~cm}$ i n di aneter to $2.4 \mathrm{~m} \mathrm{I} \mathrm{ong}$ and $10 \mathrm{~cm}$ in di aneter. In the l over end of the fl une, a sti ck $1.4 \mathrm{~m} \times 13 \mathrm{~cm}$ and another $2.0 \mathrm{~m} \times 2 \mathrm{~cm}$ l odged in two different pl aces. In the second trial with the BF4, a I og jamformed at the sane site as the fi rst: it contai ned four sticks between $1.8 \mathrm{~m}$ and $2.4 \mathrm{~m}$ four nore bet ween 1.2 and $1.8 \mathrm{~m}$ and 24 that were I ess than $1.2 \mathrm{~m} \mathrm{i}$ l ength. Four sti cks I odged i $\mathrm{n}$ the I ower secti on of the fl une: one was bet ween $1.8 \mathrm{~m}$ $2.4 \mathrm{~m}$ two more were bet ween 1.2 and $1.8 \mathrm{~m}$ and one was 1 ess than $1.2 \mathrm{mi}$ l ength.

Nearly every sti ck I odged in the BF2. Once one stick I odged behi nd a baffle, a debris jam qui ckly forned at that I ocation.

The nanner in which the sti cks I odged behi nd baffles was consi stent. The downstream end would be poi nted i nto the upstreamcorner of the baffle where it attached to the wall and floor. The back end of the stick was carried by the current to the opposi te si de of the fl une, where the current kept it pushed agai nst the upstream baffle. Sti cks that uere I onger than the wi dth of the fl une I odged fi rst, creating a si te for snaller debris to col lect. 
Di el Vari ation in Basel i ne Corti sol Concentrations and Effects of Li qht

Intensity

Cortisol Concentrations in Chinook Salmon Held in 168-L Tanks

Corti sol concent rati ons were I ower in ni ght ti me sampl es (99.4 $\mathrm{ng} / \mathrm{mL}$ ) than in dayti me sampl es $(119.5 \mathrm{ng} / \mathrm{mL}$ ) and thi $s$ di fference was si gni fi cant $(P=0, a)$. Corti sol concentrati ons in fish hel $d$ i $n$ darkened or undarkened tanks did not differ si gnificantly. These resul ts confi rma diel cycle in pl asma corti sol concent rations i $n$ fi sh hel $d$ i $n$ both darkened and undarkened tanks ( Fi g. 2).

Cortisol Concentrations in Chinook Salmon and Steel head Trout Held in Raceways

During the first trial with chi nook sal mon the barrier in the covered raceway broke free someti ne bef ore the fourth sampling, al I owing snol ts access to the rest of the raceway and I owering the densi ty to a thi rd of that for the uncovered raceway. The results of this tri al were used in the anal ysi s because val ues uere si $\mathrm{milar}$ to those of the second trial and a thi rd trial was not possible.

PI asma corti sol concentrations of chi nook sal mon were si gnificant ly l ower at ni ght than during the day, i ndi cating a diel cycle ( Fi g , 3). Corti sol concentrations were si milar in fi sh from covered and uncovered raceways, except during the fi rst few hours after I oadi ng (fi rst sample, 1600 h).

PI asma corti sol concentrations i n steel head trout di d not differ si gni fi cantl y bet ween dayti ne and ni ght $t$ i me sampl es, nor bet ween sampl es from covered and uncovered raceways. Pl otted over ti me, the data do not denonstrate a di el corti sol cycle ( Fi g. 4).

Effect of Reduced Light Intensity on Cortisol Concentrations in Chinook Salmon and Steel head Trout

M dday I i ght i ntensi ti es rangi ng from 3800 to $<0.1$ I ux di d not si gni fi cant l y affect corti sol concent rati ons i $n$ chi nook sal non or st eel head snol ts ( $P=0$ 8; Tabl e 9). 


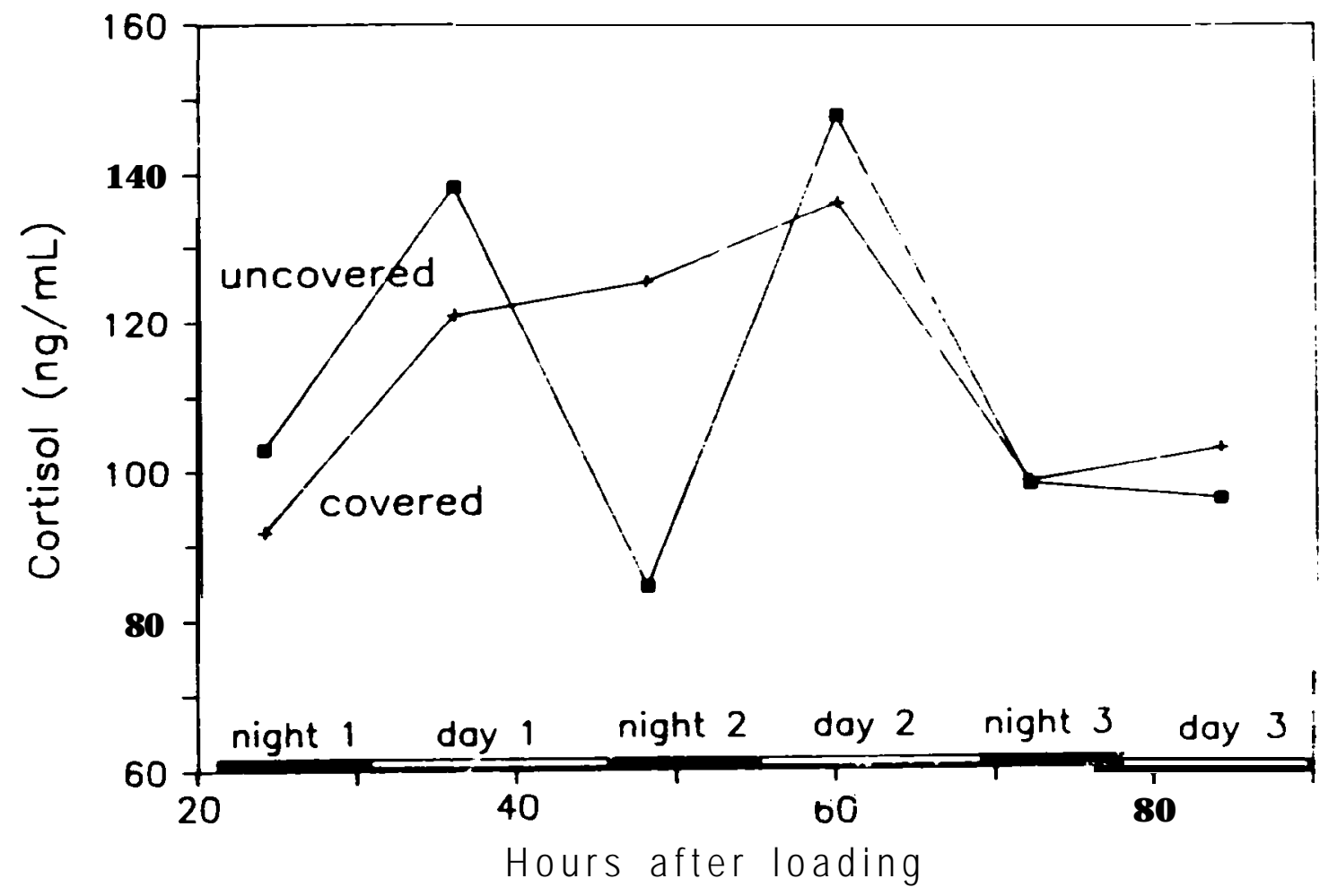

Fi gure 2. Di el fl uct uati ons i n pl asma corti sol concentrations i n chi nook sal mon snol ts hel d in darkened and undarkened 168- $L$ tanks. 


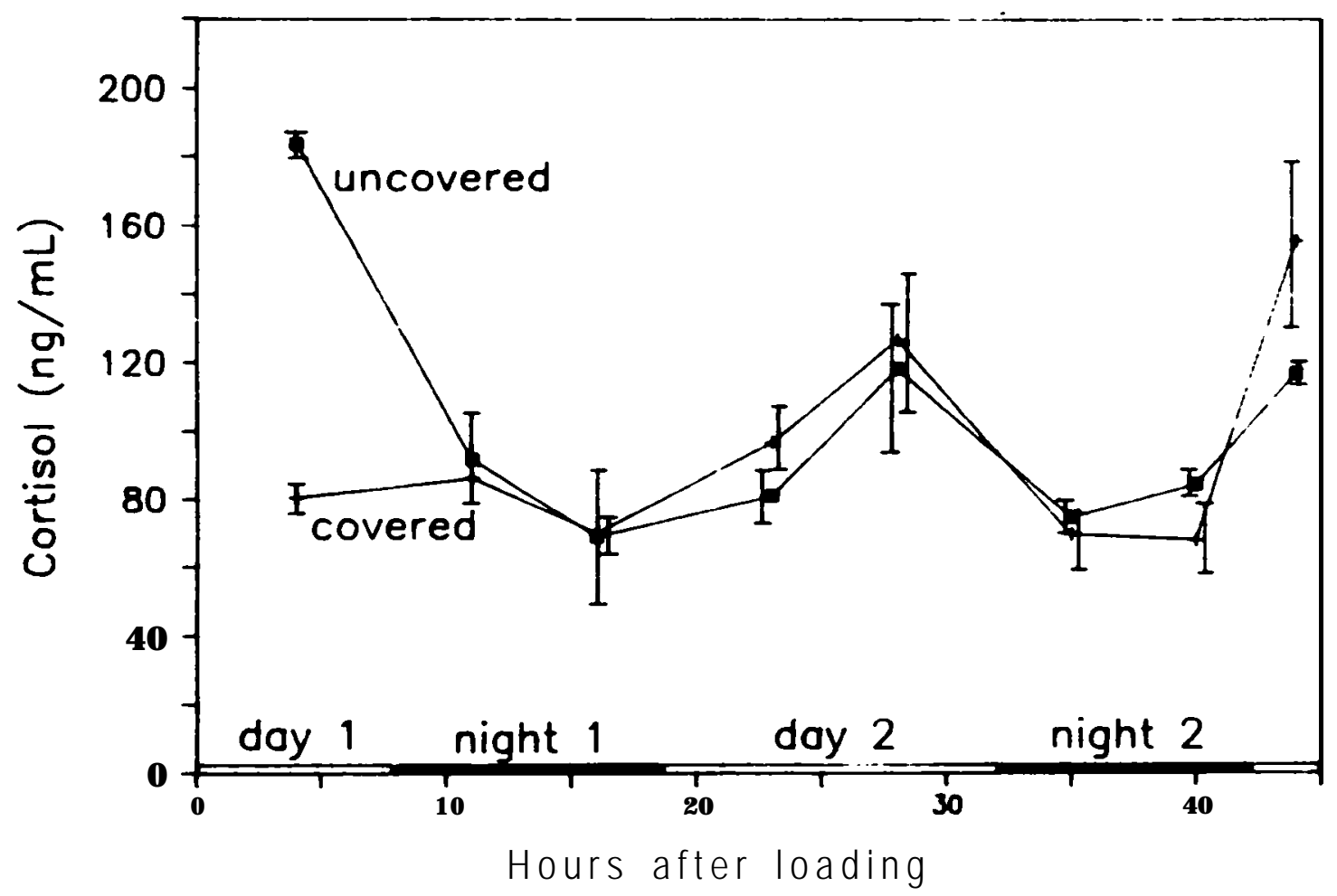

Fi gure 3. Diel fl uct uations in pl asma corti sol concentrations in chi nook sal mon snol ts hel d in covered and uncovered raceways. 


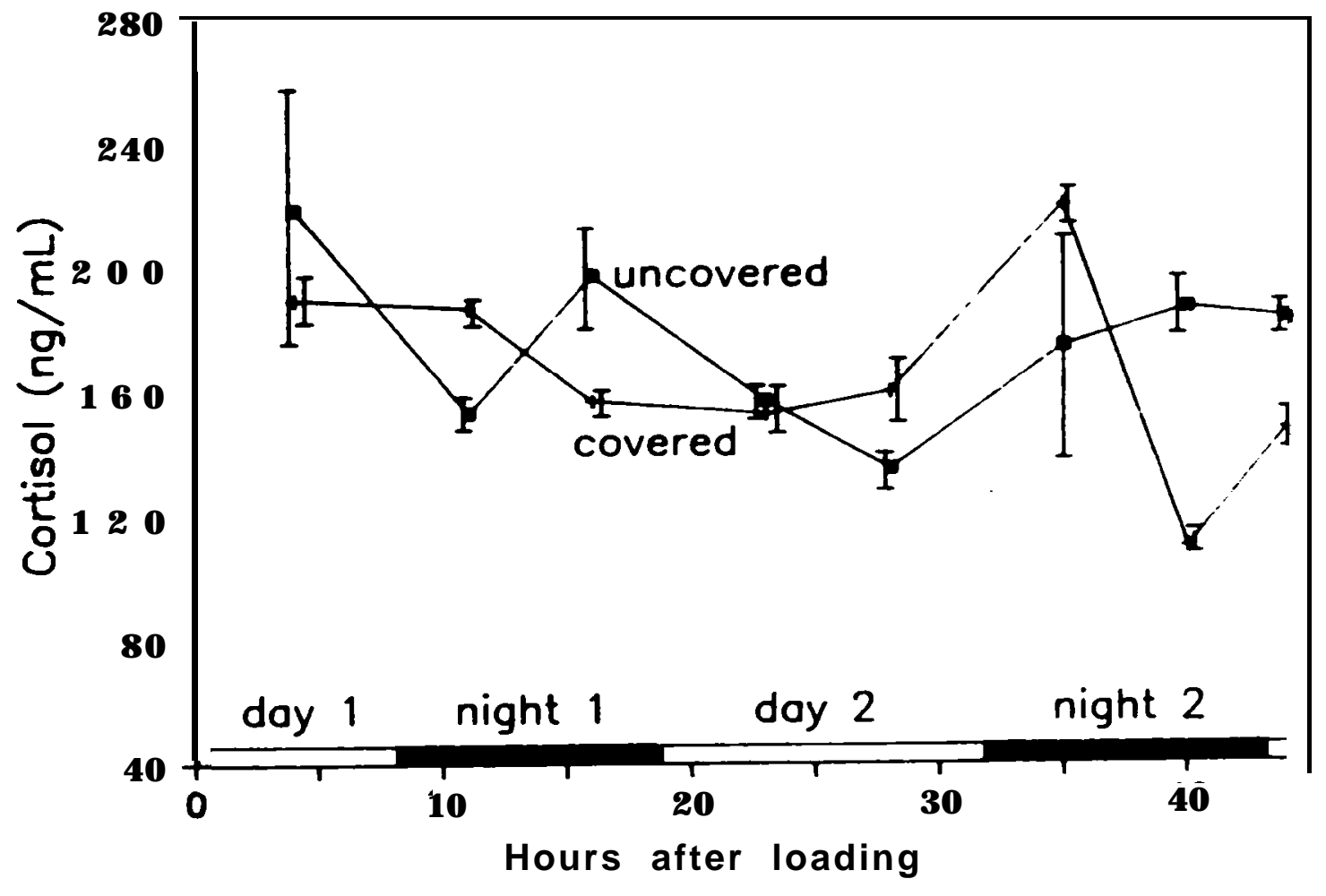

Figure 4. Diel fl uct uati ons in pl asma corti sol concent rati ons i n steel head trout snol ts held in covered and uncovered raceways. 
Tabl e 9. Mean pl asma corti sol concentrations ( $\mathrm{ng} / \mathrm{mL}, \pm \mathrm{SE}, \mathrm{N}=2$ tri al s) i n chi nook sal non and steel head trout snol ts hel d in 168-c tanks under four I i ght i ntensi ti es.

\begin{tabular}{|c|c|c|c|c|}
\hline \multirow[b]{2}{*}{ Speci es } & \multicolumn{4}{|c|}{ M dday Li ght I ntensi ty } \\
\hline & 3800 lux & 470 I ux & $4 \operatorname{lux}$ & $\cos 1$ I ux \\
\hline Chi nook S. & $124.0 \pm 54.5$ & $134.7 \pm 38.6$ & $133.2 \pm 36.3$ & $151.8 \pm 34.0$ \\
\hline St eel head & $214.7 \pm 41.3$ & $222.6 \pm 38.3$ & $258.4 \pm 47.9$ & $204.8 \pm 15.8$ \\
\hline
\end{tabular}

Cortisol Concentrations in Isolated Chinook Salmon

Fi sh that were physi cal ly but not vi sual I y i sol ated di d not have si gni fi cantly hi gher or l ower corti sol concentrati ons than fi sh that were both physi cal Iy and vi sual I y i sol ated i $n$ ei ther covered or uncovered $t$ anks ( Tabl e 10). ANOVA showed that tri al s were si gni fi cantl y di fferent, but subsequent compari son of neans usi ng Tukey's HSD test showed no correl ation bet ueen pl asma cortisol concentrations and the type of i sol ation. There was no si gnificant difference bet ueen $f i$ sh hel $d$ in darkened or undarkened tanks $(P=0.7)$.

Mean corti sol concent rati ons i $n$ fi sh sampl ed at $\mathrm{ni}$ ght $(123.5 \mathrm{ng} / \mathrm{mL}$ ) were si gni fi cantl y l ower ( $P=0.000)$ than those sampl ed during the day $(189.1 \mathrm{ng} / \mathrm{mL})$. Thi s is consi stent with the resul ts of other tests i $\mathrm{n}$ whi ch ni ghtti ne corti sol concentrati ons vere I ower than dayt i me concent rati ons.

Tabl e 10. Mean cort i sol concent rati ons ( $\mathrm{ng} / \mathrm{mL}$; $+\mathrm{SE}, \quad \mathrm{N}=12$ ) i $\mathbf{n}$ chi nook sal mon snol ts hel d i ndi vi dual I y i n covered and uncovered tanks, vi sual I y i sol ated or not i sol ated from adj acent snol ts.

\begin{tabular}{|c|c|c|c|c|}
\hline \multirow{2}{*}{$\begin{array}{l}\text { Vi sual } \\
\text { I sol at } i \text { on }\end{array}$} & \multicolumn{2}{|c|}{ Covered } & \multicolumn{2}{|c|}{ Uncovered } \\
\hline & Day & N ght & Day & Night \\
\hline \multicolumn{5}{|l|}{$\mathbf{N b}$} \\
\hline $\begin{array}{l}\text { Trial } 2 \\
\text { Mean }\end{array}$ & $\begin{array}{l}\mathbf{4 6 3 . 5} \pm 10 \hat{.5} \\
183.8\end{array}$ & $\begin{array}{l}180 . \overline{2} \pm 10.9 \\
120.4 \pm 10.0\end{array}$ & $\begin{array}{l}326.1 \pm 19.3 \\
175.1 \pm 22.6 \\
250.6\end{array}$ & $\begin{array}{r}119.2 \pm 15.8 \\
73.6 \pm 2.2 \\
96.4\end{array}$ \\
\hline \multicolumn{5}{|l|}{ Yes } \\
\hline $\begin{array}{l}\text { Tri al } \\
\text { Mean }\end{array}$ & $\begin{array}{l}153.8 \\
146.0\end{array}$ & $\begin{array}{l}182.2 \pm 18.0 \\
169.2 \pm 37.6\end{array}$ & $\begin{array}{l}142.2 \pm 1.0 \\
210.0 \pm 31.1 \\
176.1\end{array}$ & $\begin{array}{l}112.5 \pm 10.4 \\
103.6 \pm 4.3 \\
108.1\end{array}$ \\
\hline
\end{tabular}




\section{DISCUSSION}

\section{Effects of Flume Passaae on Corti sol Concentrations}

PI asma corti sol concentrations i n chi nook sal mon snol ts were not si gni ficantly increased by passage through any of the three flumes tested in 1987. To the contrary, in dayti me tests corti sol concentrations were consi stent ly l ower i $n$ fi sh sampl ed one hour af ter $f$ l ume passage (postpassage samples) than in fish that did not experience fl une passage (basel i ne sampl es). I n earli er tests (Congl et on and Ri nge 1985), corti sol concentrations were al ways higher in fish that passed through the fl unes than in fish that did not. A so, in the 1985 tests fish that passed through the CMF during the day had si gnificantly higher corti sol concentrations than fish that passed through the BF2 (the BF4 was not tested in 1985). Factors that my have contributed to the differences between 1985 and 1987 resul ts are di scussed bel ow

Basel i ne corti sol concentrations in chi nook sal mon snol ts were in cl ose agreenent in 1985 and 1987 ( Fi g. 5; di fferences 2- 7 ng/ mL). Fandl ing procedures and hol ding conditions were si milar in the two years, so agreenent in basel i ne cortisol concentrations indi cates that the two year-cl asses of snol ts responded si milarly to the noderate stress of conf i nement.

Comparison of postpassage cortisol concentrations indicated that ni ghtti me passage through the BF2 and CMF el i cted si milar corti sol responses i $\mathbf{n} 1985$ and 1987 (di fferences 9-16 $\mathbf{n g} / \mathbf{~ m L}$ ), agai $\mathbf{n}$ i ndi cat i ng a si milar stress response by the two year-classes of snolts. In contrast, dayti me passage through both f I umes resul ted i n consi derabl y I ouer corti sol concentrations in 1987 than in 1985, particularly in tests wi th the CMF ( 39 ng/ mL I ower in 1987 tests wi th ful ly covered BF2; 94 ng/ mL l ower in tests with fully covered CMF).

The maj or di fference in test condi ti ons in 1985 and 1987 was that the fl unes and the fish receiving tanks at the dounstream end of the f I unes were darkened for the 1987 dayti ne tests. I n 1985 the f I ume i nteri ors were unpai nted and the fl unes were uncovered; in 1987 the i nteri ors were pai nted a dark gray-brown insi de and the fl umes were covered with ei ther perforated plate or opaque plastic. We concl ude that these changes are responsible for the l over postpassage corti sol concentrations in 1987 . The l owered cortisol response was nost pronounced in the CMF, which had a highly reflective interior before painting. Addi ti onal evidence of an effect of I i ght on cortisol is provided by the fact that postpassage cortisol concentrations were si gnificantly l ower in 1987 dayti ne tests with ful I y darkened f I unes than in tests wi th parti al I y darkened fl unes. This fi ndi ng can be attributed sol el y to the difference in I ight intensity within the fl unes under the two test conditions.

The decline in plasme cortisol concentrations in chi nook sal non snol ts after passage through the fl umes in 1987 dayti me tests are thought to have been a consequence of: 1 ) rel ati vel y stressf ul condi tions in the 


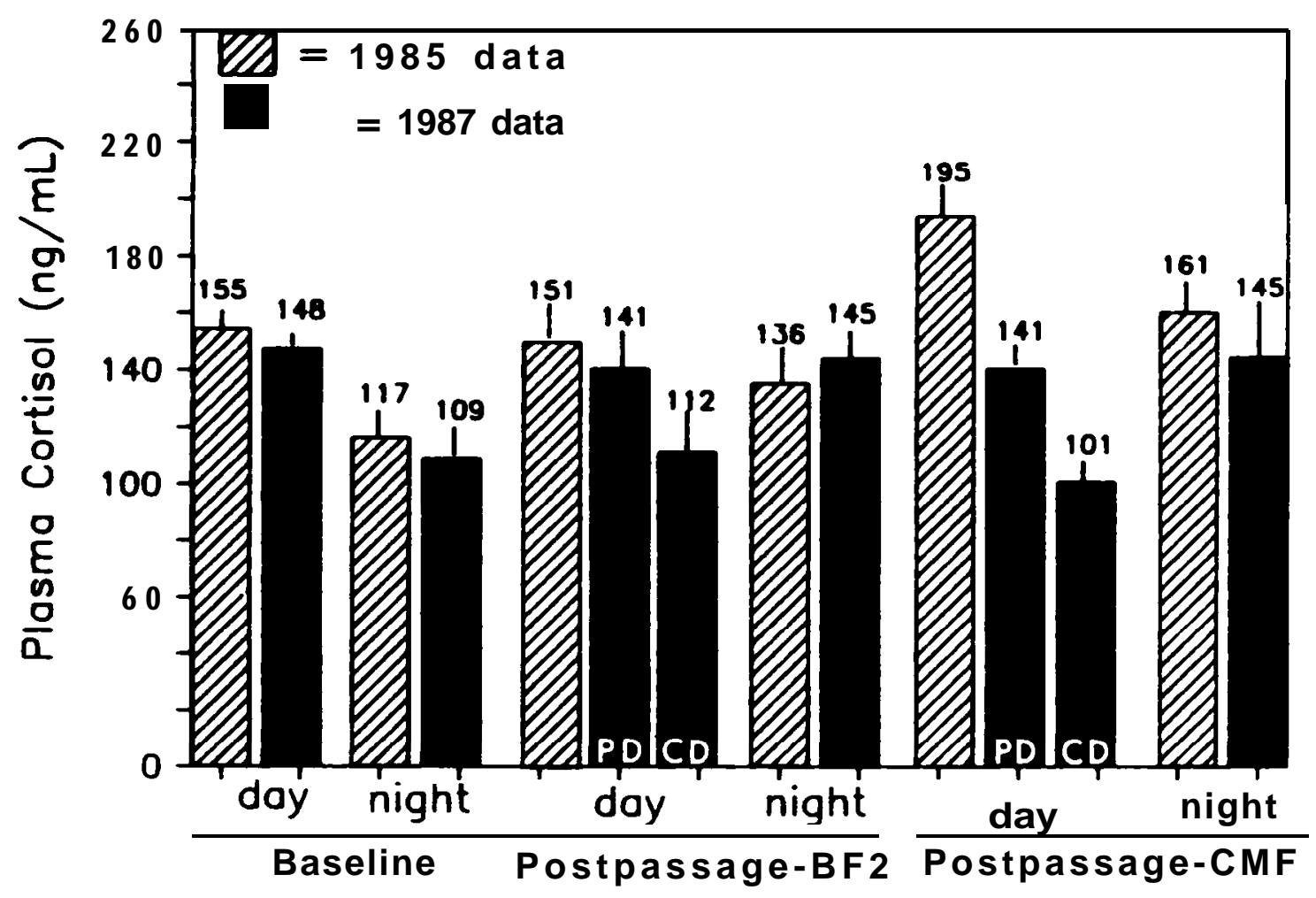

Fi gure 5. Compari son of mean corti sol concentrati ons ( $\pm S E$ ) bet ween basel i ne and fil une post passage sampl es in chi nook sal non sampl ed i n 1985 and 1987 during the dayti me (uncovered in 1985; partially darkened (PD), or compl et el y darkened (CD) in 1987) or ni ghtti me. 
hol di ng tanks (possi bl y because of smal I vol une), 2) the absence of a strong stress response to passage through darkened fl unes, and 3) rel ati vel y unstressful conditions ( I arge vol une, darkness) in the fish recei vi ng tanks.

In contrast to resul ts with chi nook sal mon smolts, pl asma corti sol concentrati ons i n steel head trout snol ts were si gnifi cantly i ncreased by fl ume passage in both dayti me and ni ghtti ne tests in 1987, wi th the smal lest increases measured in fish that passed through the CMF and the I argest in fish that passed through the BF2. These results differ from those obtai ned with steel head in the 1985 tests, when snol ts that passed through the CMF in dayti me tests had a si gnificantly greater i ncrease in cortisol than fish that passed through the BF2 (data for both years are summari zed in Appendi x C). Factors that nay have contri buted to the differences bet ween 1985 and 1987 results are di scussed bel ow

Basel i ne cortisol concentrations in steel head smol ts were noderatel y hi gher ( 18- $30 \mathrm{ng} / \mathrm{mL}$ ) i n 1987 than i $\mathbf{n} 1985$. Compari son of changes i $\mathbf{n}$ cortisol concentrations fol I owing ni ght ti ne fl ume passage i ndi cates snal l er (25-46 ng/ mL) i ncreases în 1987. Dayti ne passage through the BF2 resulted in simiar el evation of cortisol in the two years, but dayti ne passage through the CMF resulted in consi derably smal ler increases in corti sol i n 1987 ( $122 \mathrm{ng} / \mathrm{mL}$ snal I er i n parti al I y darkened fl une, 93 ng/ mL smal l er in ful I y darkened f I ume).

The differences between 1985 and 1987 cortisol data for steel head are minor, except for the much smaller cortisol increase in fish passing through the CMF in 1987 dayti me tests. Thi s reduced response to CMF passage i ndi cates that darkening of the CMF and recei vi ng tank ef fecti vel y reduced the stress response of steel head smol ts to fl une passage. However, compl ete darkening of the CMF di d not l ower post passage corti sol concentrations in steel head trout to a greater extent than did partial darkeni ng, in contrast to fi ndi ngs with chi nook sal mon.

The reasons for a greater el evation of pl asma corti sol in steelhead that passed through the baffled fl unes in compari son with steel head that passed through the CMF are unknown. El evation of cortisol may have been rel ated to the duration of fl une passage, which was briefer for the CMF (0.5-2.0 min) than for the baffled flumes (2-10 min).

\section{Descaling of Smol ts i n Fl unes}

I ndi ces of descal ing ( nean percentage of body surface descal ed and percentage of descal ed $\mathrm{fi}$ sh) i ndi cated no si gni ficant i ncrease in descal ing after fl une passage and no si gnificant effect of flune design. Therefore, descaling was not a problem with any of the fl une designs test ed. 


\section{Behavior of Adult Chinook Salmon in Flumes}

The upstream migration of adul $t$ spring chi nook sal non in the Snake Ri ver coi nci des with the downstream mi grati on of chi nook sal mon and steel head trout snol ts i $\mathbf{I}$ ate Apri I and May. Some adul t sal mon becone di soriented after passing through fish Iadders at the dans and "fal I back" into the turbi ne intakes, event ual I y entering the $\mathrm{j}$ uveni l e bypass systens at Lover Granite and Little Goose Dans. These "fal I back" adults are strong swi mers and coul d concei vabl y remi $n$ i $n$ a I ow vel oci ty baff l ed bypass system for a l ong ti me, but the adul ts we tested di not do so. Loss of the balloon attached to the fish made conti nuous observation of l ocati on i mpossi bl e i $n$ one test, but adul ts passed qui ckl y ( $<2.3 \mathrm{mi} \mathrm{n}$ ) through the fl umes in the renai ni ng 7 tests. I nf erences from these observations must be I i mited, because onl y four adul t chi nook sal non were tested; the responses of sone adul $t$ chi nook sal mon to a baffled fl une could differ from the responses of the few fish we tested.

\section{Passaae of Debris Throuah Flumes}

A number of pi eces of noody debri s l onger than 0.8-0.9 m l odged in the BF2 and debri s I onger than 1.4-1.8 mlodged in the BF4. A I arge anount of debris $1.4 \mathrm{~m}$ and greater in length enters the bypass system at Little Goose Dam in years when river fl ow is normal or above normal (Sarah Vil I i s, COE, personal commini cation). Ther ef ore, l odgi ng of debri s in a 2-foot or 4-foot wi de fl une at Little Goose Dam could create a mai nt enance problem if a debris separator were not installed at the upstream end of the fl une. Al debris tested passed readi Iy through the CMF, so a debris separator could be instal led at ei ther the upstream or downstream end of thi s fl une.

\section{Diel Vari ation in PI asna Corti sol Concentration and Ef fects of}

\section{Li ght Intensi tv}

Evi dence for a reduced stress response to fl une passage in darkened fl umes was summari zed in the preceding section. Thi s evi dence is based on comparison of changes in pl asma cortisol foll owing passage through open f I umes in 1985 and darkened fl umes in 1987, and on the fi ndi ng that cortisol concentrations in chi nook sal non after passage through completel y darkened fl umes were si gnificantly I ower than af ter passage through parti al I y darkened fl unes in 1987. Addi ti onal tests were performed in 1987 specifically to determine the effects of I ight on pl asma cortisol concentrations in conf $i$ ned but otherwi se undi st urbed chi nook sal non and steel head trout snol ts.

Pl asma corti sol concentrations were si gni fi cantly hi gher in dayti me than in ni ghtti me sampl es of chi nook sal non smol ts hel d for 48 hours in raceways and for 60 hours in 168- $L$ tanks. Thi s di el cycle was unaf fected by I ight intensity: cortisol concentrations in fish sampled concurrently 
from darkened and undarkened tanks and raceways di d not di ffer si gni fi cantl y. A di el cycle in pl asma corti sol and gl ucose concentrations uas previ ously reported in chi nook sal non smol ts exi ting the bypass pi pe at the Lower Granite Dam fi sh hol ding facility (Congl et on et al. 1984).

A di el cycle i n pl asma corti sol concentrati ons was not evi dent i n steel head trout hel d in raceways. However, corti sol concentrations were consi stently and si gni ficantly hi gher in dayti me than in ni ghtti me basel i ne sampl es of steel head in 1985 and agai $n$ in 1987, i ndi cating a probabl e di el corti sol cycle in this species al so.

Di el cycles i n pl asma corti sol have been previ ously reported i $\mathbf{n}$ adul t sal noni ds (Pi ckeri ng and Potti nger 1983, $N$ chol s and Wei sbart 1984), but not i $n$ j uveni l e rai nbow trout (Barton et al. 1980), cutthroat trout or chi nook sal non (Strange et al. 1977). Rance et al . (1982) reported a di el corti sol cycle i $n$ i mat ure rai nbow trout (mean wei ght 253 g) i $\mathbf{~ J ~ u l ~ y , ~ b u t ~}$ not in Decenber under a short photoperiod. In al l previ ously reported i nstances of di el corti sol cycl es i n sal noni d fi shes, peak corti sol concentrations have occurred in the nightti me rather than in the dayti ne. The dayti me peak in pl asma corti sol in chi nook sal mon snol ts may be rel ated to the $i$ ni ti ation of downstream migration in the earl y hours of darkness, si nce the di el corti sol maxi mum in hi gher vertebrat es typi cal I y occurs a few hours in advance of the period of peak activity (Mbore-Ede et al. 1982).

Diel cycles in plasma corti costeroi d concentrations have been studi ed nore extensi vel y than cycles in any other endocri ne system i n hi gher vertebrates (Kri eger 1979). These cycles are generated by a pacemaker in the central nervous system (endogenous rhythn) rather than sol el y by response to sone peri odic external sti mul us (exogenous rhythm). Endogenous cycl es of ten have a ci rcadi an peri odi city slightly I onger than 24 hours, but are reset by daily exposure to an envi ronmental sti mul us such as the diel li ght cycle. Ther ef ore, endogenous corticosteri od cycles are "free-runni ng" and conti nue in ani mals transferred from a nat ural photoperi od to constant I i ght or dark, but gradual ly I ose synchrony with the natural I ight cycle.

In our tests a diel corti sol cycl e conti nued i n chi nook sal non snol ts hel d i n "darkness"; however, true darkness could not be attai ned under fi el d conditions. Dayti ne Ii ght intensiti es vere I-4 I ux in fully covered raceways and $<0.1 \mathrm{I}$ ux in tanks with opaque $\mathrm{I} i \mathrm{ds}$. Ther ef ore $\mathrm{fi}$ sh hel d i n "darkness" experi enced an attenuated di el I i ght cycle, and further tests under constant I i ght condi ti ons would be necessary to test the hypothesis of a free-running endogenous cortisol cycle.

An al ternati ve expl anati on for the di el corti sol cycle i n chi nook sal non snol ts is that vi sual percepti on of conf $i$ nenent stress might vary on a diel basi s (Schreck 1981). Snol ts hel d in 168- L tanks were moderatel y stressed: cortisol concentrations in fish sampled at ni ght were $25 \mathrm{ng}$ hi gher than in snol ts sampl ed from raceways at ni ght and 25- 80 ng/ $\mathrm{m}$ hi gher than in snol ts sampl ed fromgatewel Is at Lower Grani te Dam 
(Congl et on et al. 1983). However, al though corti sol concentrati ons were l ouer in snol ts confined in raceways than in snol ts confined in tanks, the ampl itude of the diel fl uct uati on was I arger in snol ts conf i ned in raceuays ( $55 \mathrm{vs} 35 \mathrm{ng} / \mathrm{I} \mathrm{m}$ ). Conti nuati on of an undampened corti sol cycl e in raceways and under very l ow Iight intensi ti es argues agai nst a pri mary rol e for vi sual perception of conf $i$ nenent stress in generation 0 the cycl e.

A thi rd al ternati ve expl anation for the di el corti sol cycle is that vi sual I y medi ated agoni stic i nteracti ons might el evate pl asma corti sol concentrati ons (Ej i ke and Schreck 1980, Nbakes and Leatherl and 1977) i n the Iight, but not in darkness. Our data failed to show a significant ef fect of vi sual i sol ation from conspecifics on cortisol concentrations in chi nook sal mon. A role for agoni stic stress can not be fi rnly rejected, however, because poor agreement bet ween replicated trials reduced the power of the test: rejection of the nul I hypothesis may have been i ncorrect.

The cortisol response by snol ts of both species to passage through darkened fl unes was greater in ni ghttti ne tests, when prestress cortisol concentrations were l ower, than in dayti me tests, when prestress cortisol concentrations were higher. A greater cortisol response in juvenile chi nook sal mon with l ower prestress pl asma cortisol concentrations was al so reported by Barton et al. (1986). Si milarly, in rats the greatest corti coster oi d response to a standardized stress occurs at the l ow poi nt in the di el corti costeroi d cycle (Dunn et al. 1972). Thi s i nverse rel ati onshi $p$ bet ueen prestress cortisol concentrations and stress-evol ked i ncreases could resul $t$ from adj ust nents in any one or nore of the several interacting processes that control pl asma cortisol l evel s. Sensitivity of the pi tui tary to CRF sti mul ation or of i nterrenal ti ssue to ACTH sti mul ati on may i ncrease during periods of reduced activity, as may al so the quantity of ACTH stored in the pituitary or of cortisol stored in interrenal ti ssue. Such changes in responsi veness or in quantities of hor nones avai l able for rel ease woul d pri ne the hypothal mi c-pi tui taryinterrenal axis for an augnented stress response.

Quantification of the stress response by measurement of changes in pl asma cortisol concentrations requi res that the cortisol response ei ther be unaffected by ti me of day and other variables or that the ef ect of these vari abl es be understood (Barton and Schreck 1987). The greater cortisol response to passage through darkened fl unes does not i mpl y that nightti ne fl une passage uas nore stressful than dayti me passage, but rather that the corti sol response varied on a di el basi s. 
Barton, B. A, R. E. Peter, and C. R. Paul encu. 1980. PI asma corti sol l evel s of fi ngerl ing rai nbow trout (Sal mo aairdneri) at rest, and subj ected to handl ing conf $i$ nement, transport and st ocki ng. Canadi an J ournal of Fi shery and Aquati c Sci ences 37: 805-811.

Bart on, B. A , C. B. Schreck, and L. A. Si gi smondi . 1986. Mul ti pl e acute di sturbances evoke cumul ati ve physi ol ogi cal stress responses in j uvenile chi nook sal mon. Transacti ons of the Aneri can Fi sheries Soci ety 115:245-251.

Bart on, B. A, and C. B. Schreck. 1987. I nf I uence of accl i mati on temperat ure on interrenal and carbohydrate stress responses in j uveni I e chi nook sal mon (Oncorhvnchus tshawutscha). Aquacul ture $62: 299-310$.

Basham L. R. , M R. Del arm T. B. Athearn, and S. W Pettit. 1982. Transport operati ons on the Snake and Col unbi a ri vers. Fi sh Transportati on Oversi ght Team Annual Report for FY 1981. NAA Techni cal Menorandum NMFS F/ MR-2. 58 pp.

Congl et on, J.L. , and R. R. Ri nge. 1985. Response of chi nook sal mon and st eel head trout smol ts to three fl unes tested at Lower Grani te Dam 1985. I daho Cooperati ve Fi sh and Vil dl i fe Research Unit Techni cal Report 86-3, Mbscowy I daho.

Congl et on, J.L., T. C. Bj ornn, C. A Robertson, J.L. I rvi ng, and R. R. Ri nge. 1984. Eval uating the effects of stress on the viability of chi nook sal non snol ts transported from the Snake Ri ver to the Col unbi a Ri ver estuary. Fi nal compl eti on report to U.S. Army Corps of Engi neers, WhI I a Ual I a Di stri ct, cont ract DACU68-83-C- 0029.67 pp.

Dunn, J., L. Schevi ng, and P. M I l et. 1972. Ci rcadi an vari ati on i n stress-evoked i ncreases i n pl asma corti sol. Anerican J ournal of Physi ol ogy 223:402-406.

Ej i ke, C. and C. B. Schreck. 1980. Stress and social hi erarchy rank i n coho sal mon. Transacti ons of the Aneri can Fi sheri es Soci ety 109: 423426.

Foster, L.B., and R. T. Dunn. 1974. Si ngl e anti body techni que for radi oi nmunoassay of corti sol i n unext racted serum or pl asma. Cl i ni cal Chemi stry 20: 365-368.

N chol s, D.J., and M Uei sbart. 1984. Pl asma corti sol concentrations i n AtI ant i c sal mon, Sal no sal ar: Epi sodi c vari ati ons, di urnal change, and short term response to adrenocorti cotropi $c$ hormone. General and Compar at i ve Endocri nol ogy 56:169-176. 
Noakes, D.L., and J.F. Leatherl and. 1977. Soci al domi nance and i nt errenal cel I acti vi ty i n rai nbow trout, Sal mo qairdneri ( Pi sces, Sal noni dae). Envi ronnent al Bi ol ogy of Fi shes 2: 131- 136.

Pi ckeri ng, A.D., and T.G. Potti nger. 1983. Seasonal and di el changes i n pl asna cortisol I evel s of the brown trout, Sal mo trutta L. General and Comparati ve Endocri nol ogy 49: 232- 239.

Rance, T.A., B.I. Baker, and G. Uebl ey. 1982. Vari ati ons in pl asma cortisol concentrations over a 24-hour period in the rai nbow trout Sal no sai rdneri. General and Comparati ve Endocri nol ogy 48: 269- 274.

Reddi ng, J.M., C.B. Schreck, E.K. Bi rks, and R.D. Ewing. 1984. Corti sol and its effects on pl asma thyroid hormone and el ectrol yte concentrations in fresh water and during seawater accl i mation in yearling coho sal non, Onchorhvnchus ki sutch. General and Comparati ve Endocri nol ogy 56: 146- 155.

Schreck, C.B. 1981. Stress and compensati on in tel eostean fi shes: Response to soci al and physi cal factors. Pages 295-321 In A.D. Pi ckering, edi tor. Stress and fi sh. Academic Press, London/ New York.

Strange, R. J., C.B. Schreck, and J.T. Gol den. 1977. Corti coi d stress responses to handl ing and temperat ure in sal noni ds. Transactions of the Aneri can Fi sheri es Soci ety 106: 213-217. 


\section{APPENDIX A \\ HYDRAULI C ANALYSI S OF FLUMES}

\section{INTRODUCTION}

Thi s report descri bes the physi cal feat ures, di scharges, wat er depths, vel ocities, and other properties associ ated with the performance of the three test flumes used in the previ ousl y describe bi ol ogi cal testing. These paraneters were fi el d neasured on 26, 27 and 29 J une, 1987.

\section{CORRUGATED METAL FLUIE (CMF)}

\section{Descri pti on}

Previ ous fi el d measurenents (i n August 1985) on thi s f I une i ndi cat ed a I ength from begi nni ng to the end of sl oped channel of $281 \mathrm{feet.} \mathrm{The}$ neasured el evation difference of 9.5 feet resul ts i $n$ an average 3. 4- percent sl ope. The fl une al i gnment has t wo 53 degree, 30-f oot radi us curves starting about 85 f eet downstream from the head tank. The sem-circul ar fl oor and vertical walls of the fI ume are made of corrugated al umi num wi th I/2-i nch corrugations on a 2-2/3-i nch spaci ng. The i ndi vi dual secti ons of the fI ume were wel ded together fol I oned by gri ndi ng to achi eve snooth $\mathrm{j}$ oi nts. The fl une di anet er neasured 34.75 i nches. Ref er to photographs in Fi gure $A 9$.

Previ ous tests (1985) in the corrugated metal fI une used dewatering screens $I$ ocated at the downstream end of the fl une. These screens renoved water from the fl une bef ore it di scharged i nt o the sampl e tank. During these tests (1987), the dewatering screens were el i mi nat ed and al I of the fl une fl ow passed i nto the sample tank. Si nce al I f I ow passed through the sample tank, it was enl arged from 5-feet wi de by I o- feet I ong (horizontal di nensi ons) to I o-feet wi de by 15-feet I ong. A so, the i nteri or of the fl ume was pai nted a dark gray-brown col or and the enti re I ength of the fl une was covered wi th perforated (51-percent open area) al umi num pl ate.

\section{Di scharqe}

Di scharge neasurements nere obtai ned by neasuring fl ow in the 30- i nch di ameter suppl y pi pe. These measurenents uere made wi th a manonet er fl ow measur enent devi ce; namel y, a Cox fl ow net er. Numerous measurements i ndi cated an average di scharge of 29.7 cfs, with fl ow varying from 28.3 to 30.7 cfs.

Measurements at the wei $r$ i $n$ the fi sh sample tank i ndi cated an approxi nate di scharge of 27.5 cfs. However, the nappe of the wei $r$ fl ow was not $f u l l y$ aerated. Theref ore, wei $r$ fl ow cal cul ati ons based on $f$ ree fl ow wei $r$ equati ons are not accurate, but do verify the magni t ude of the fl ow meter readi ngs. 
Sone I eakage occurred in the vi ci nity of the fl une head tank. Thi s l eakage was mor and was not quantified.

Depth and Vel ocity

At several l ocations al ong the length of the corrugated netal $f($ une, depths and poi nt vel ociti es were neasured. At the upstream end of the fl une (start of the corrugations), the water depth was 23.0 inches with an average vel ocity of $6.4 \mathrm{fps}$. A average normal depth of 17.0 i nches was achi eved at approxi matel y 20 feet from the transition. The corresponding average vel ocity for this depth was $9.3 \mathrm{fps}$.

At the beginning of the shape transition, depth decreased and vel ocity i ncreased. The decreasi ng depth and i ncreasi ng vel ocity ended w th an undul ar (very weak) hydraul i c j ump, creat ed by the I arger depth of water in the fish sample tank. The upstream Froude number for the j ump, F1, was approxi natel y 1.25. Specifically, the water depth decreased from 16. 25 to 11.9 i nches i medi at el $y$ upstream from the $j$ ump and the vel ocity i ncreased to $15.2 \mathrm{fps}$. The I ength of the hydraulic j unp was approxi natel y 15 feet and ended with an average wat er depth in the fl une of 32.5 i nches fl owing i nto the fi sh sample tank at an average vel ocity of $3.8 \mathrm{fps}$.

Fi gure $A$ illustrates the fl ow profile and vel ocities at the fl une centerli ne in the I ower shape transition of the corrugated metal fl ume. Fi gures $A 2, A 3$, and $A 4$ show poi nt vel oci ty neasurements at sel ected cross-secti ons in the fl ume upstream from the fi rst curve, miduay through the first curve, and downstream from the second curve, respect i vel $y$.

\section{Curve Effects}

The 53-degree, 30- $f$ oot radi us curves of the corrugated metal $f \mathrm{l}$ une created a water depth difference of about four i nches bet ueen the water surfaces at the inside and outsi de of the curve. Refer to Figure $\mathbf{A} 3$.

\section{TMO-FOOT WIDE BAFFLED FLUIE (BF2)}

\section{Descri pti on}

By previ ous fi el d measurements in August, 1985, the I ength of thi s fl une was neasured as 113.0 feet from the begi nni ng to the end of the sl ope. The measured el evati on di f f erence of 4.0 feet resul $t s$ i $n$ an average 3.5-percent sl ope. The fl une was constructed of pl yuood (and I at er I i ned with fi bergl ass to reduce I eakage during the 1987 tests) with 24-i nch by 24-i nch cross sectional area. Baffles of fi bergl ass were bol ted onto the fI ume wal Is on al ternating 2-foot centers. The baffles protrude into the fl ow area about 8 inches l eaving a fl ow area wi dth of 16 inches at the baffle tip. A 53-degree, 24-foot radi us curve occurs about $\mathbf{3 0}$ feet downstream from the fl une head tank. For the 1987 
tests, this fl ume was al so modified by ti nting the fibergl ass $I i$ ner the the gray-brown col or and covering the fl ume with perforated (51-percent open area) al um num $\mathrm{pl}$ ate. The $\mathrm{fl}$ ume was operat ed so that al I fl ow passed through the sample tank. Refer to photographs in Fi gure A $\mathbf{O}$

Di scharqe

The operating discharge for this fl une was 4.8 cfs as measured using the Cox fl ow meter l ocated in the 30-i nch di aneter suppl y pi pe. FI ow vari ed from 4. 6 to 5.1 cf s during measurenent of the di scharge. Leakage from the fl une uas $\mathrm{mi}$ mal at the ti ne of measurement.

Depth and Vel ocity

The baffled $f($ une mai ntai ned a rel ati vel y constant water depth of 19. 5 i nches. The depth was slightly hi gher at the downstream end of the fl ume sl ope due to tail water effects from the fi sh sample tank.

Vel ocity measurements were taken at several locations al ong the I ength of this flume. Figures A5 and A6 represent typical cross-sections through the fl une with Figure A5 I ocated at the baffle ti $p$ and Fi gure $A 6$ equi di st ant bet ween baffl es. The maxi mum measured vel ociti es nere j ust downstream from the baffle tip in the center of the channel and were approxi matel y 4 to 4.5 fps. M ni mum vel ociti es were di rectl y dounst ream from each baffl e and were near $0 \mathrm{fps}$. The head drop from the upstream to dounstream si de of each baffle was approxi natel y 3 i nches.

\section{Curve Effects}

No specific effects to the fl ow were attri butable to the 53 degree, 24-f oot radi us curve.

FOUR-FOOT WIDE BAFFLED FLUNE (BF4)

Descri pti on

Thi s f I une repl aced the 8. 3-percent sl ope BF2 fI une used in the 1985 tests. Fi el d measurenents of thi s f I une i ndi cat ed a I ength of 119.6 f eet from the begi nni ng to the end of the sl ope. The measured el evation di fference of 4.1 feet resul ts i $n$ an average 3.4-percent sl ope. The fl ume uas constructed of concrete with 48-inch by 48-inch cross-secti onal area. Baffles of $f i$ bergl ass were bol ted ont o the $f l$ ume wal Is on al ternating 4-foot centers. The baffles protrude into the fl ow area about 16 i nches I eavi ng a fl ow area wi dth of 32 i nches at the baffle tip. Thi s fl ume does not have a curved al i gnnent. Perforat ed (51-percent open area) al uni num pl ate al so covered the top of this fl une. Ref er to photographs in Fi gure All. 


\section{Di scharge}

Di scharge measurements were obtai ned by measuri ng fl ow in the 30- i nch di aneter suppl y pi pe. Numer ous Cox fl ow net er neasur enents i ndi cated an average di scharge of 24.8 cfs, wi th fl ow varyi ng from 24.3 to 25.1 cfs.

Measurements at the wei $r$ in the fi sh sampl e tank i ndi cated an approxi mate di scharge of 20.6 cfs. However, the nappe of the wei $r$ fl ow was not $f u l l y$ aerated. Ther ef ore, wei $r$ fl ow cal cul ations based on free fl ow wei $r$ equati ons are not accurate, but do verify the magni tude of the f I ow neter readi ngs.

Leakage from the fl une was mi mal at the ti me of measurenent.

Depth and Vel ocity

The baffl ed fl ume mi ntai ned a rel ati vel y constant water depth of 29. 0 i nches. However, actual water depth vari ed sl i ght l y at each baffle.

Vel ocity measurenents were taken at several I ocations al ong the I ength of this flume. Figures $A 7$ and $A 8$ represent typical cross-sections through the fI une with Figure $A 7$ located at the baffle ti $p$ and Fi gure A8 equi di stant bet ween baffl es. The naxi mum neasured vel ociti es were downstreamfromthe baffle tip in the center of the channel and were approxi matel y 4.5 to $5.5 \mathrm{fps}$. M ni mum vel oci ti es were di rectl y downstream from each baffl e and were near $0 \mathrm{fps}$. The head drop from the upstream to downst ream si de of each baffle was approxi matel y 5.5 to 6 i nches. 


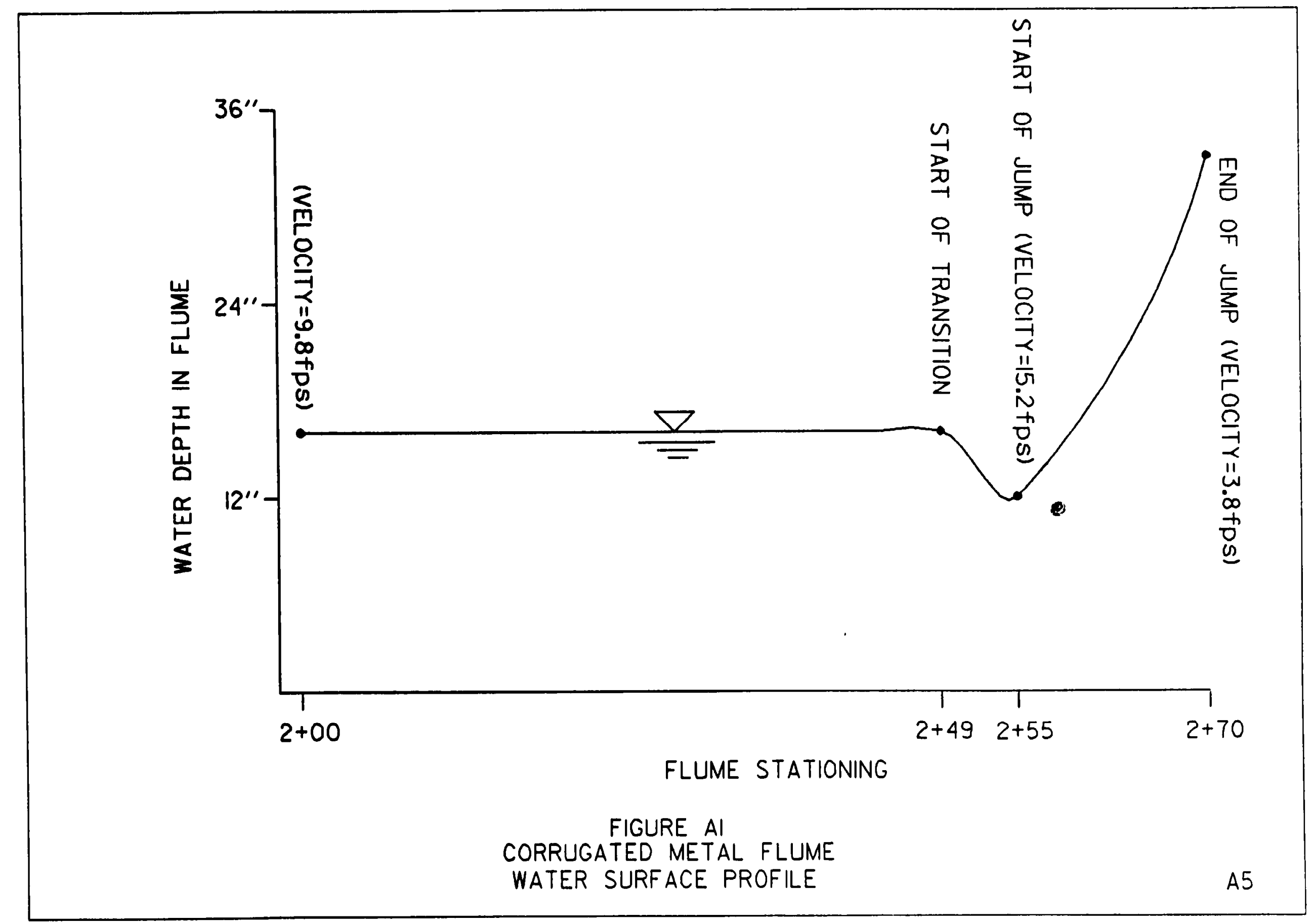




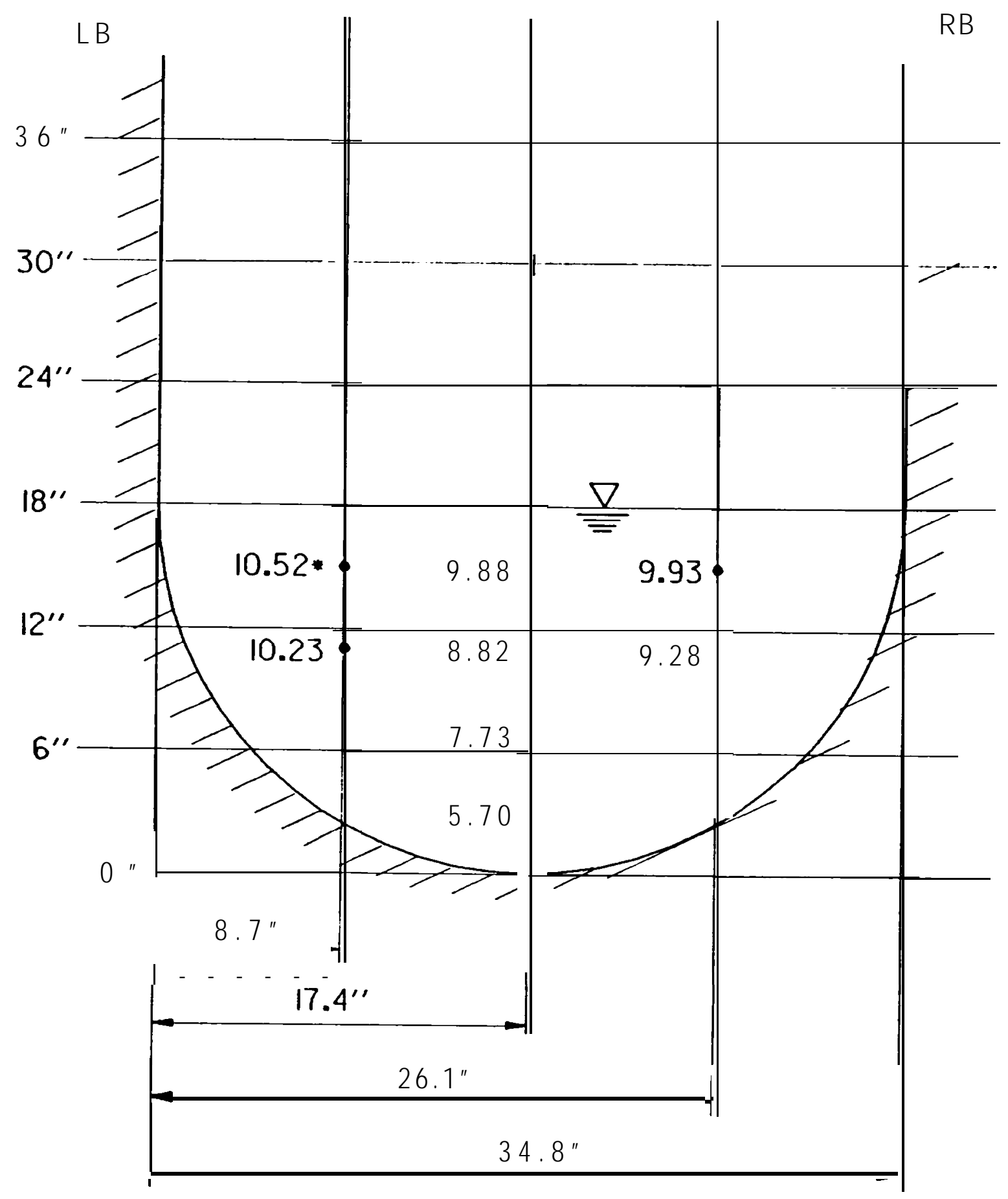

- POINTS WITHIN FlOW SECTION REPRESENT VELOCITY IN FEET PER SECOND.

FIGURE A2

CORRUGATED METAL FLUME

(3.4\% SLOPE)

$S T A 0+20.0$ 


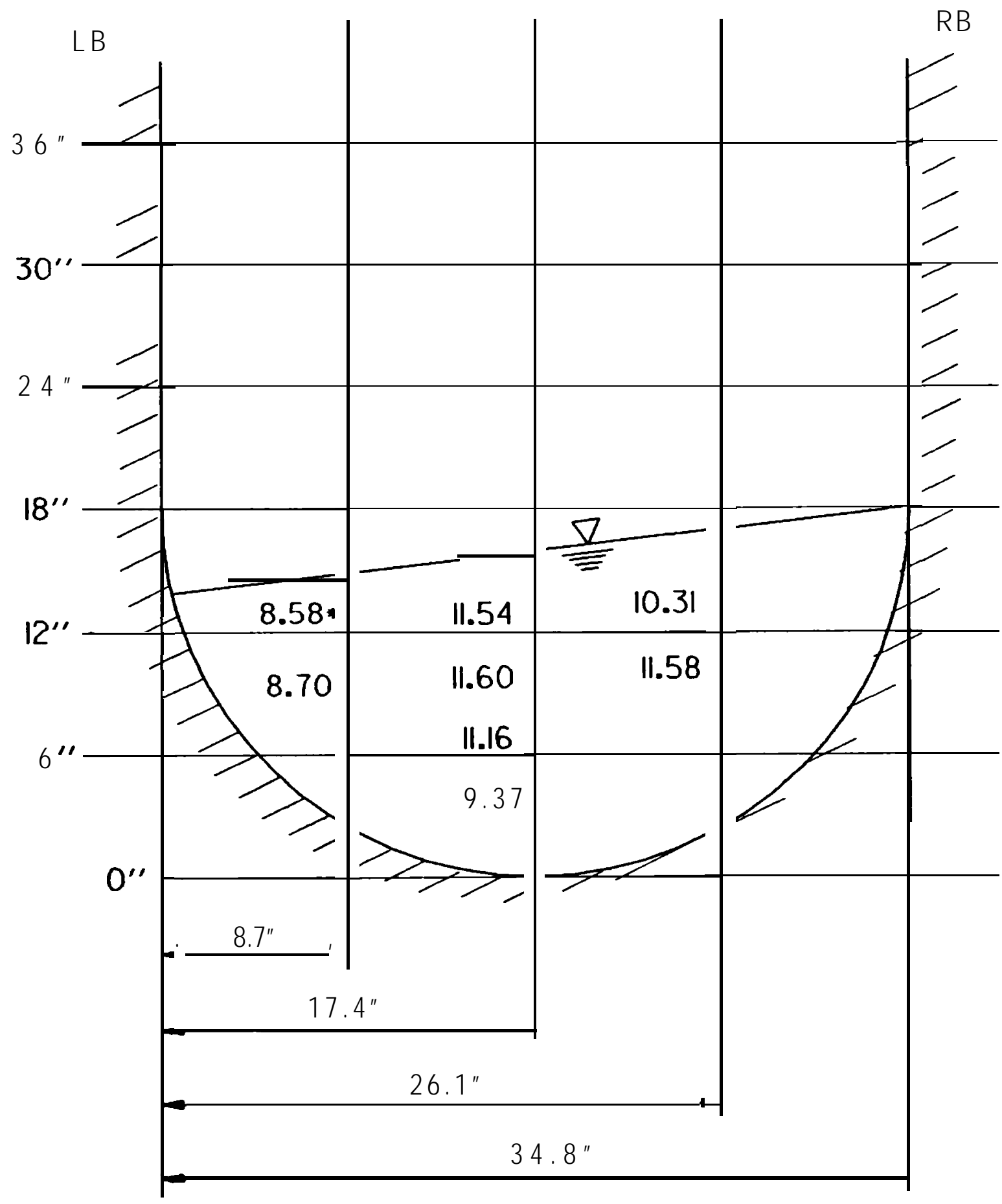

- POINTS WITHIN FLOW SECTION REPRESENT VELOCITY IN FEET PER SECOND.

FIGURE A3

CORRUGATED METAL FLUME

(3.4\% SLOPE)

$S T A 0+94.0$

(MIDWAY THROUGH FIRST CURVE) 


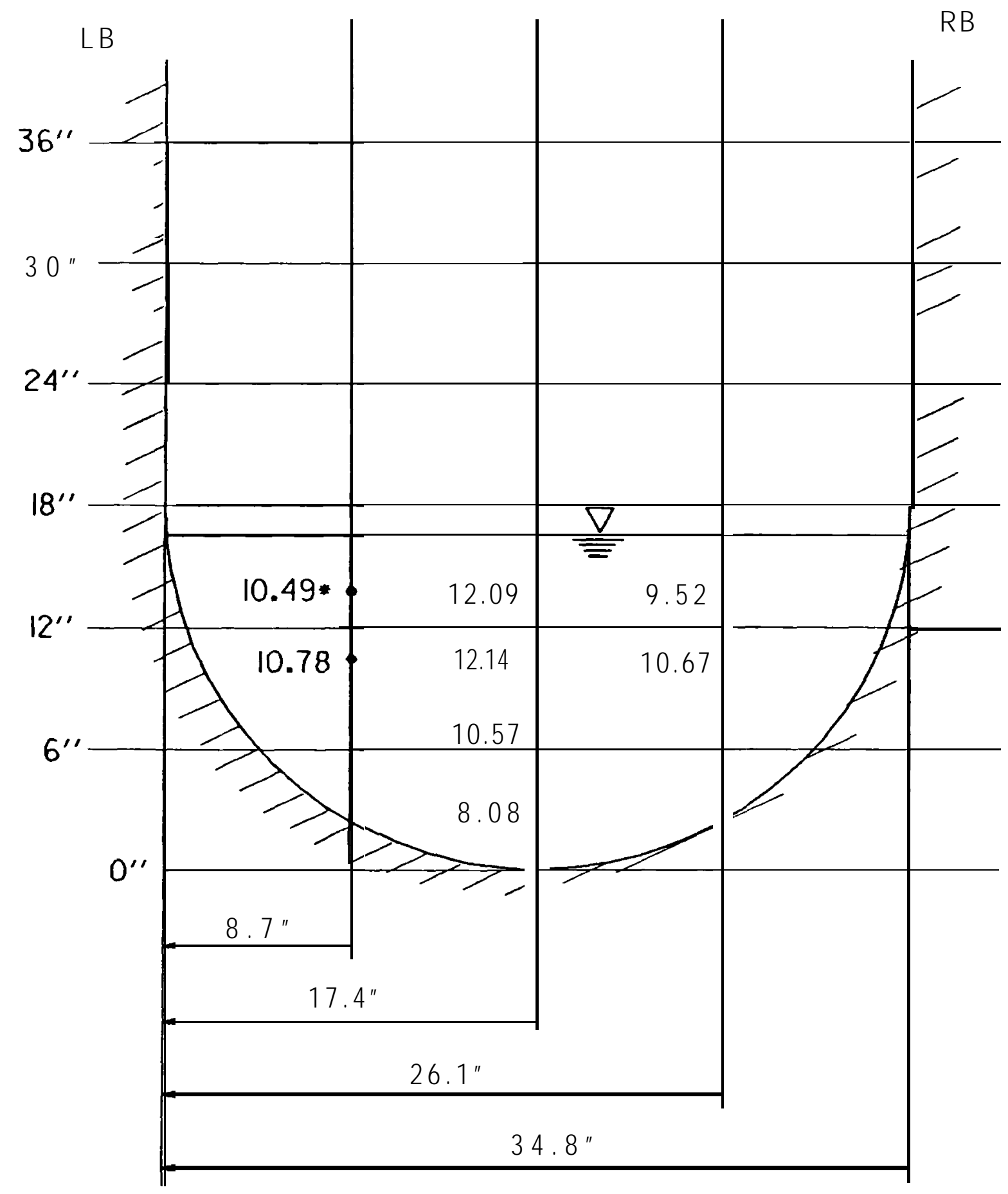

* poINTS Within flow SECtion REPRESENT VELOCITY IN FEET PER SECOND.

FIGURE A4

CORRUGATED METAL FLUME

(3.4\% SLOPE)

STA $2+00.0$ 


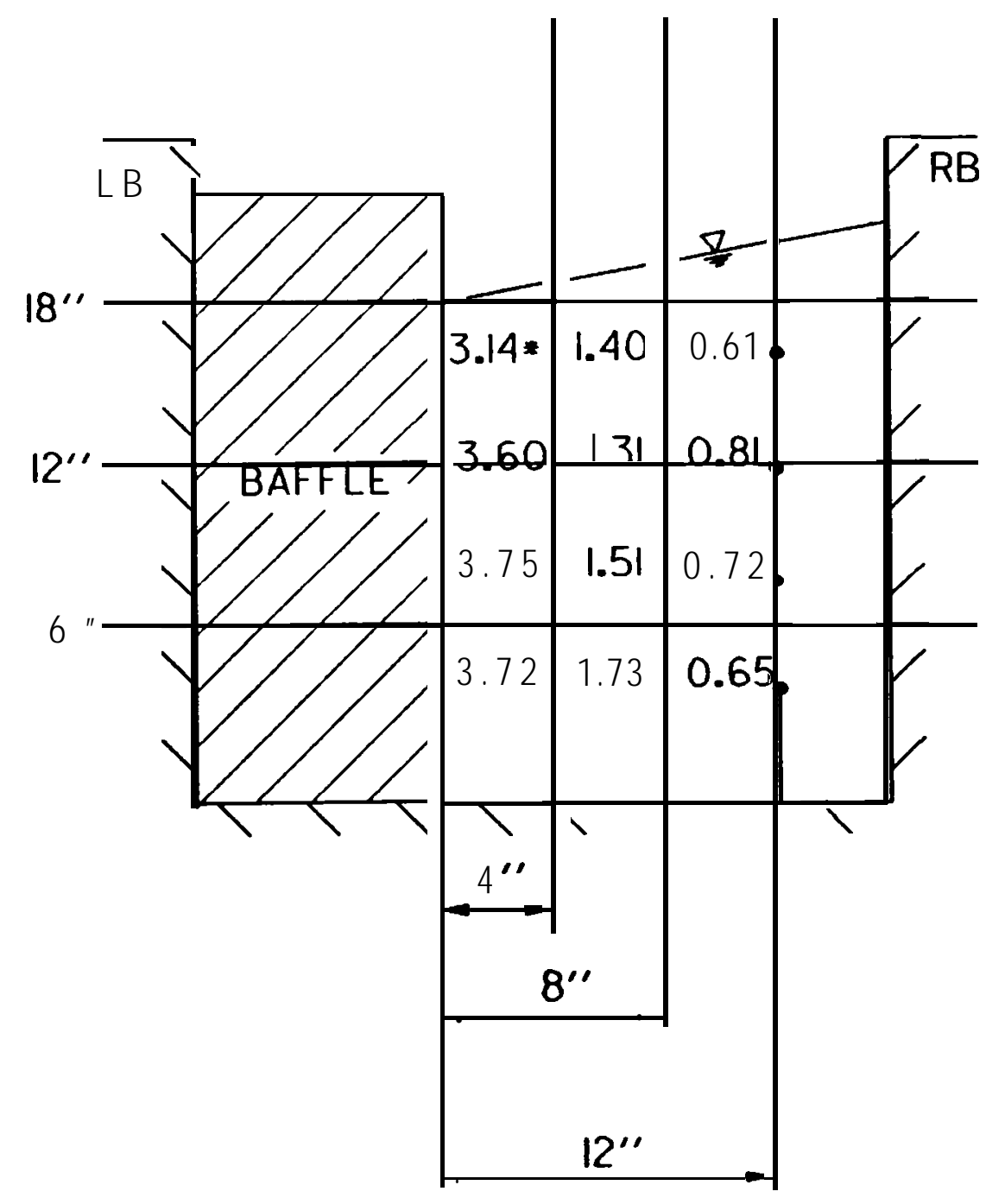

- POINTS WITHIN FLOW SECTION REPRESENT VELOCITY IN FEET PER SECOND.

FIGURE A5

2' WIDE BAFFLED FLUME

(3.4\% SLOPE)

STA. $0+70.0$ 


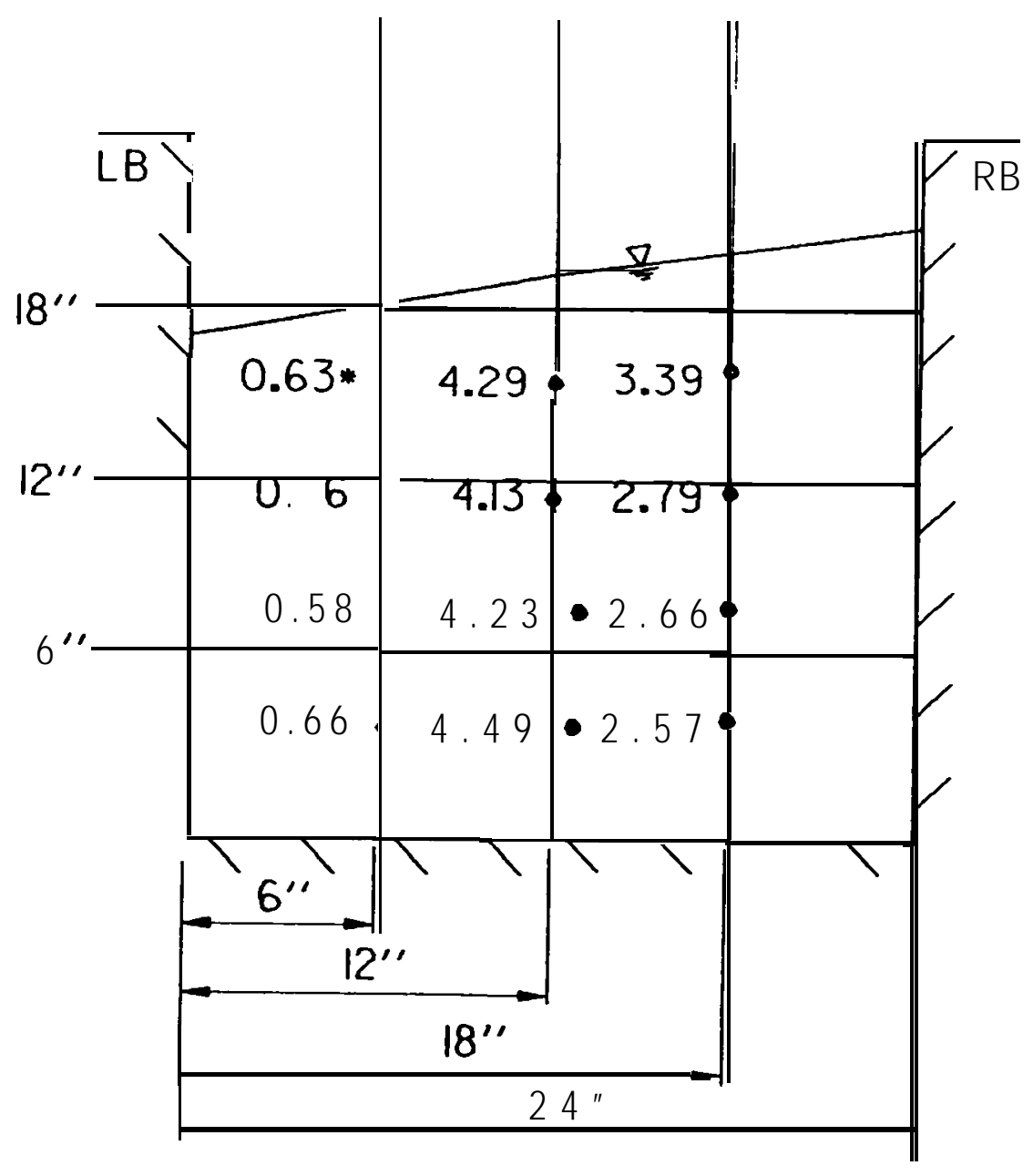

- POINTS WITHIN FLOW SECTION REPRESENT VELOCITY IN FEET PER SECOND.

FIGURE A6

2' WIDE BAFFLED FLUME

(3.4\% SLOPE)

STA. $0+71.0$ 


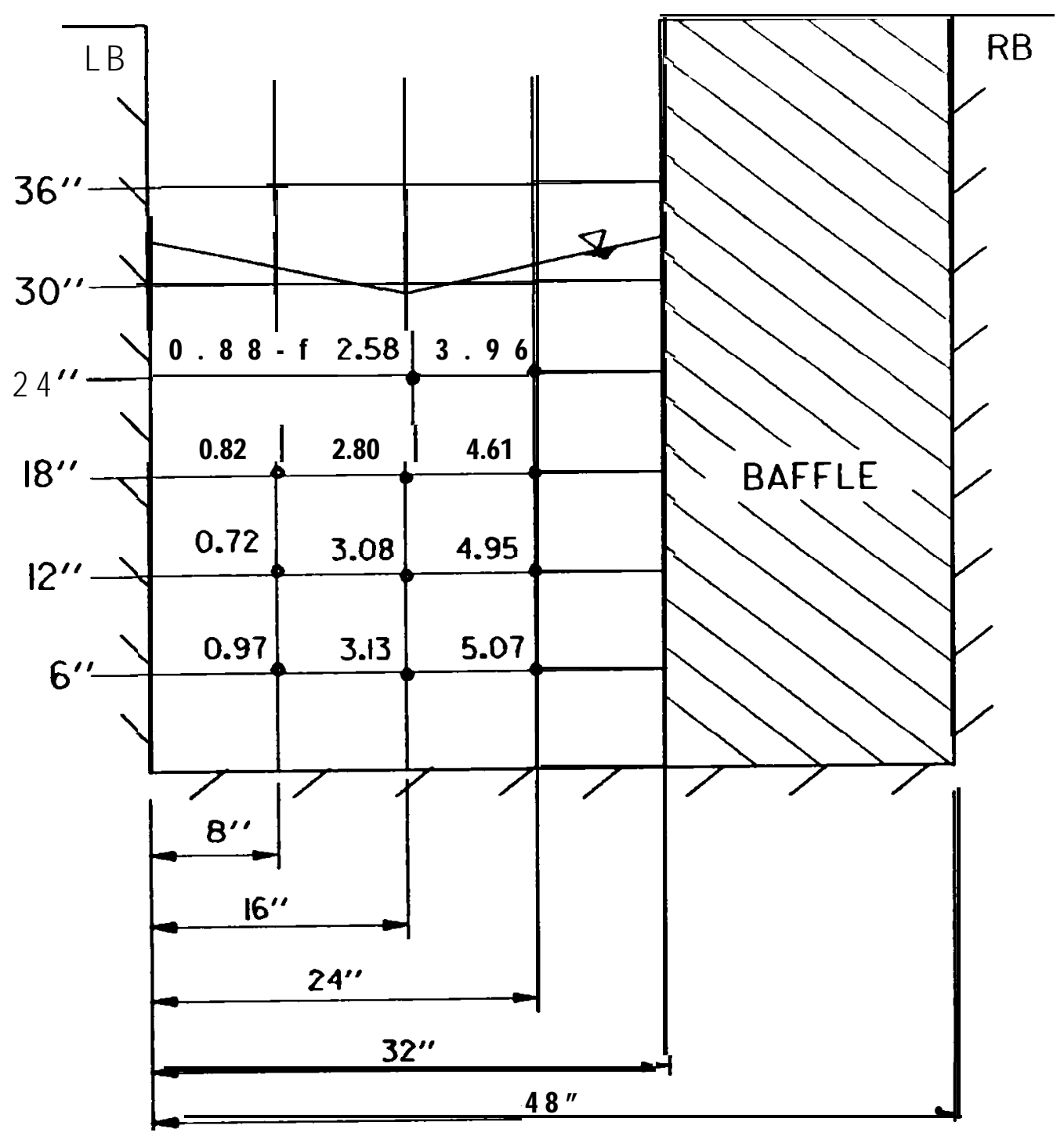

- pOINTS WITHIN FLOW SECTION REPRESENT VELOCITY IN FEET PER SECOND.

FIGURE A7

4' WIDE BAFFLED FLUME

(3.4\% SLOPE)

STA. $0+44.6$ 


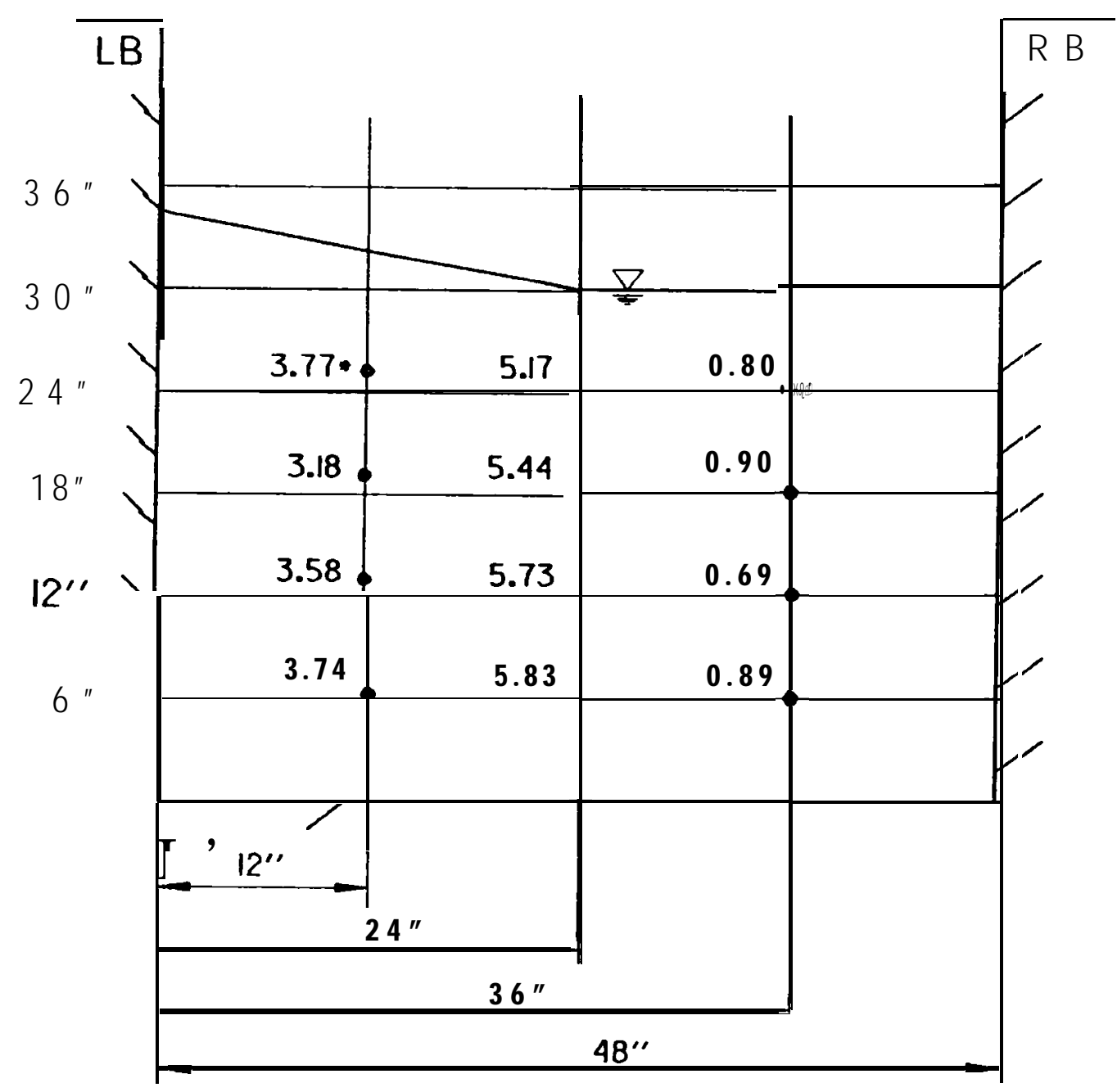

- points within flow section represent VELOCITY IN FEET PER SECOND.

FIGURE A8

4' WIDE BAFFLED FLUME

(3.4\% SLOPE)

STA. $0+47.0$ 


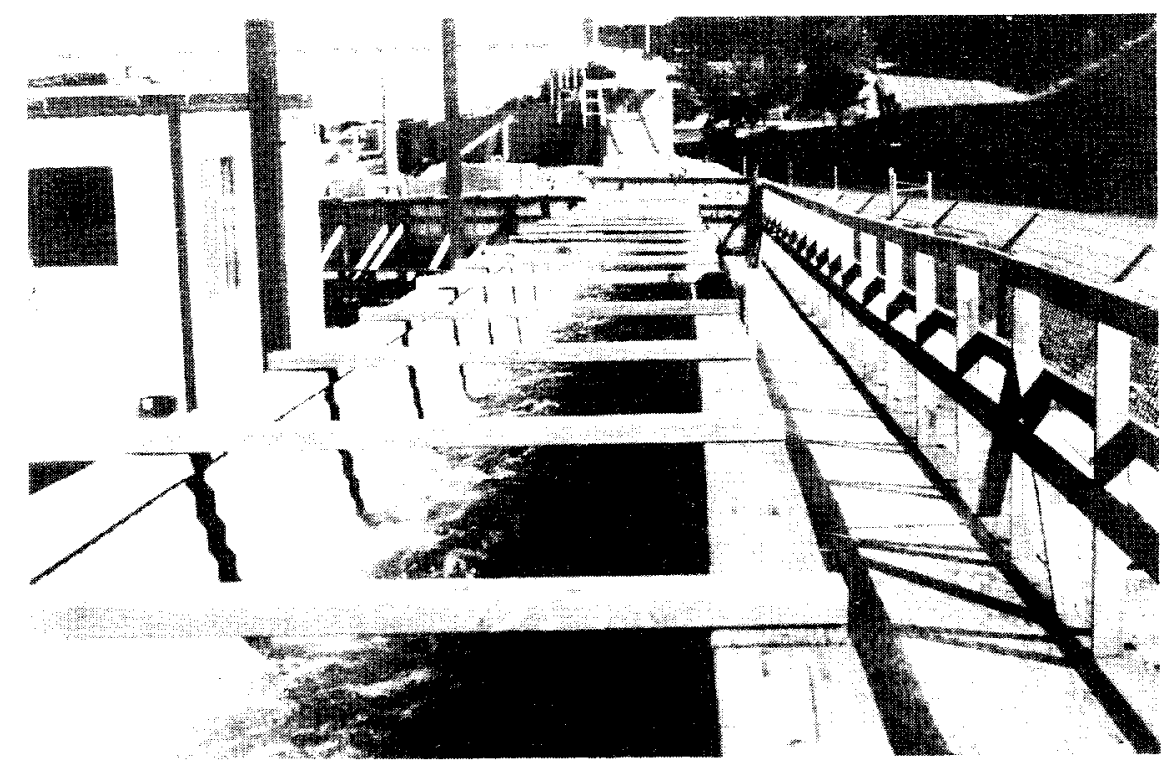

LOOKING DOWNSTREAM

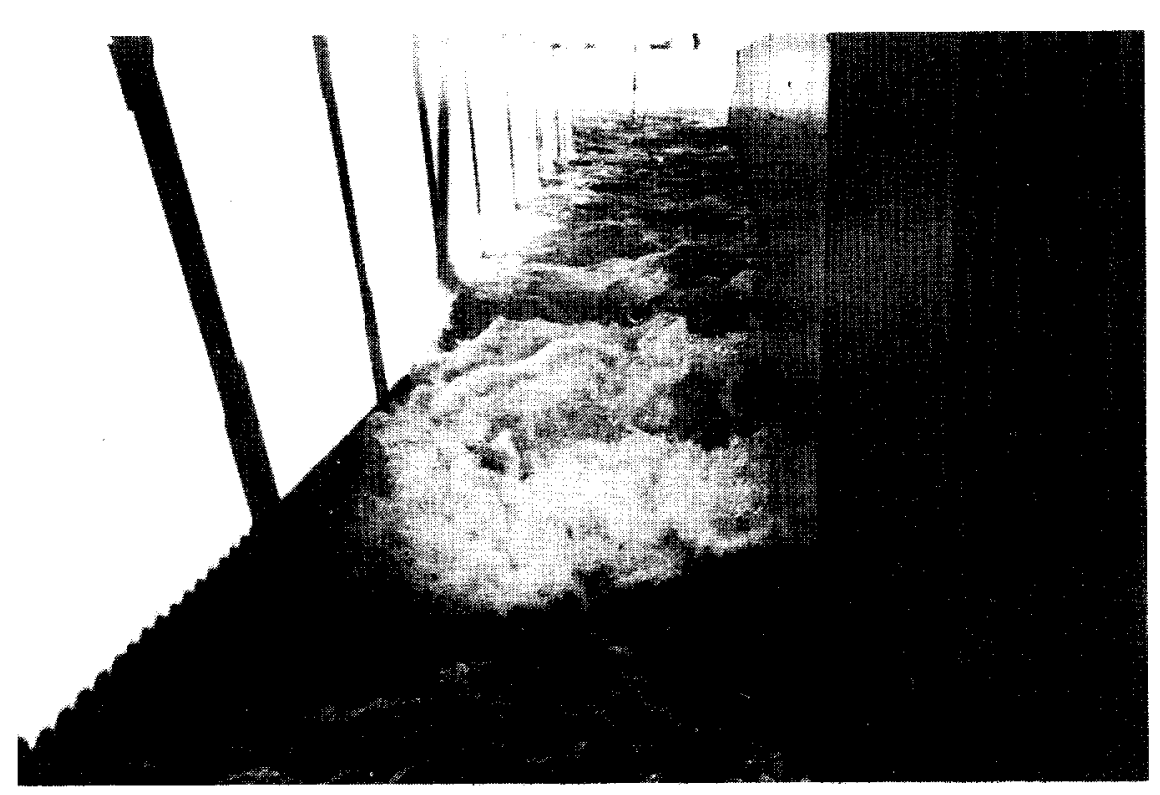

HYDRAULIC JUMP AT SHAPE TRANSITION

FI GURE A9

CORRUGATED METAL FLUME 


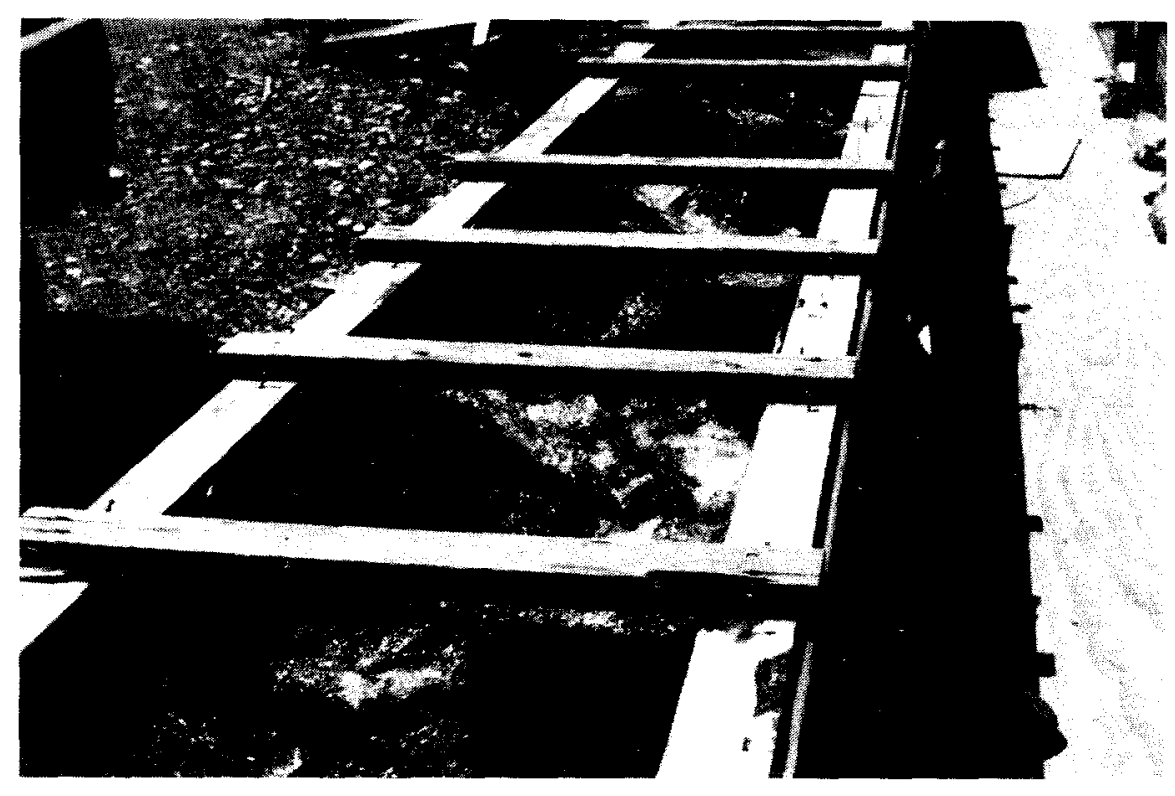

LOOKING UPSTREAM

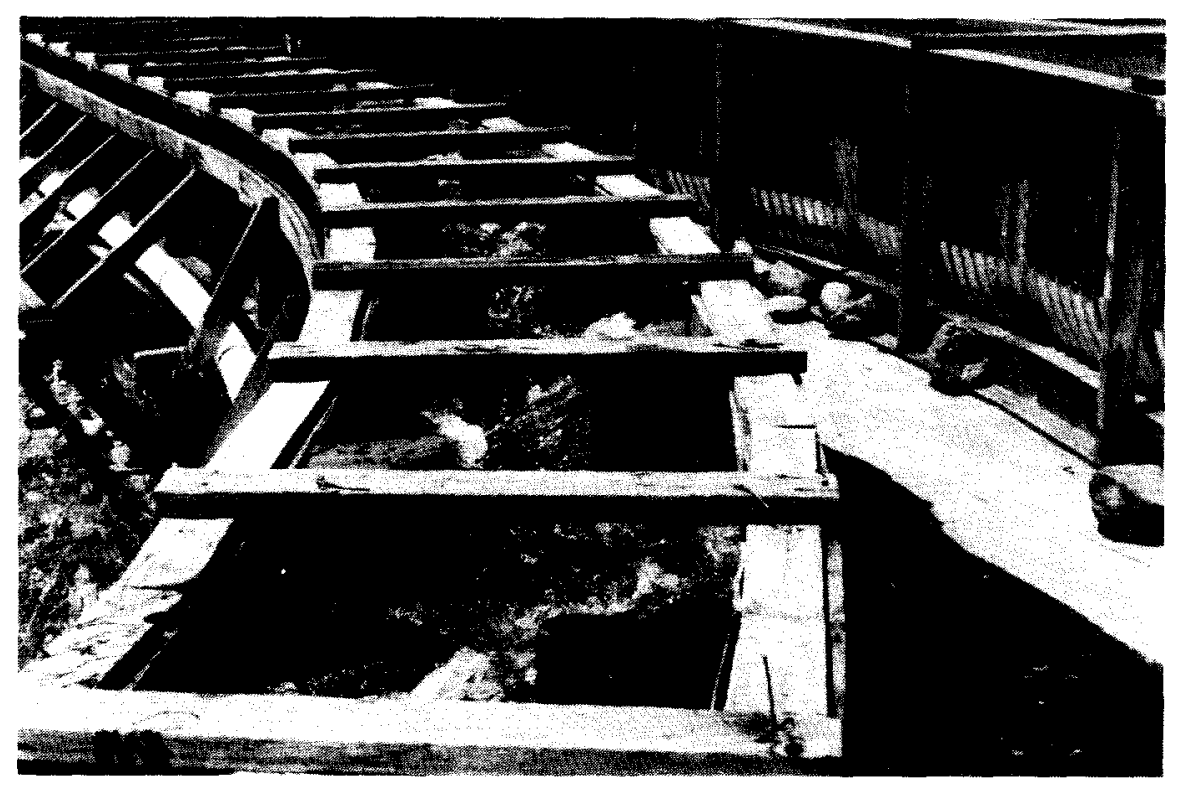

LOOKING UPSTREAM

\section{FIGURE AI0 \\ 2' WIIDE BAFFLED FLUME}




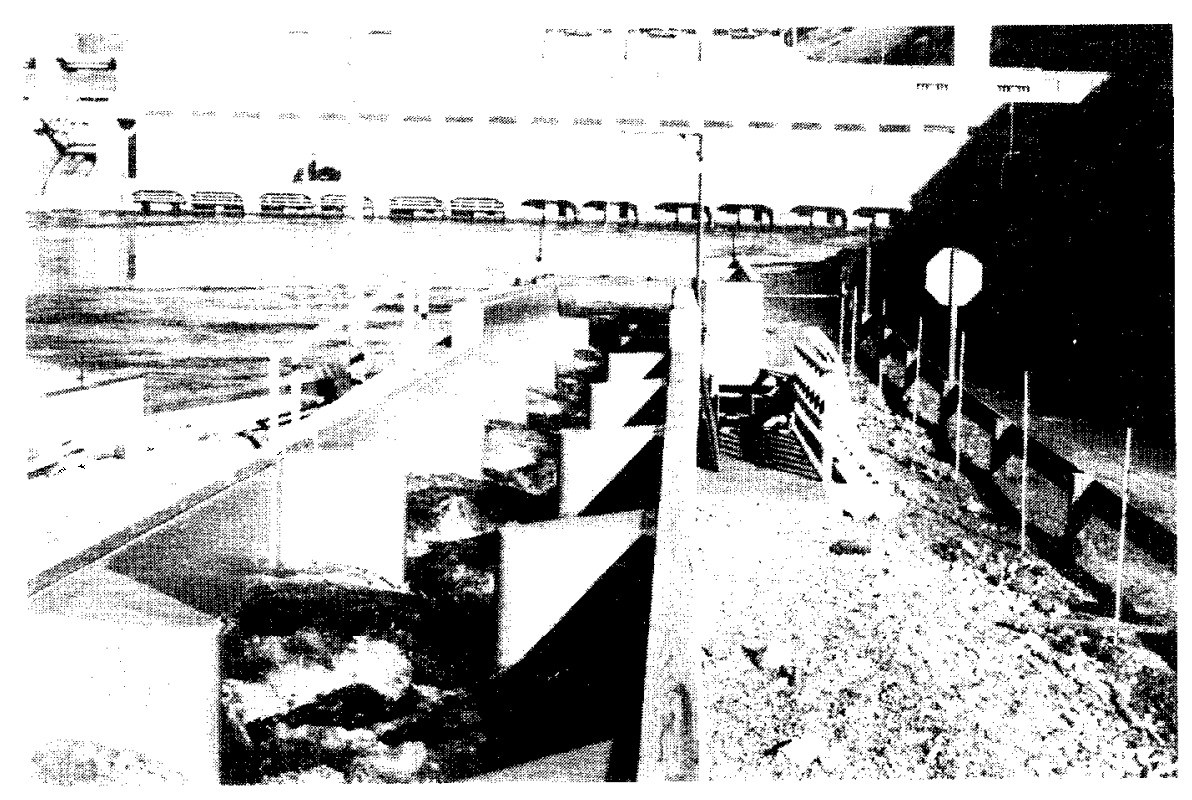

LOOKING DOWNSTREAM

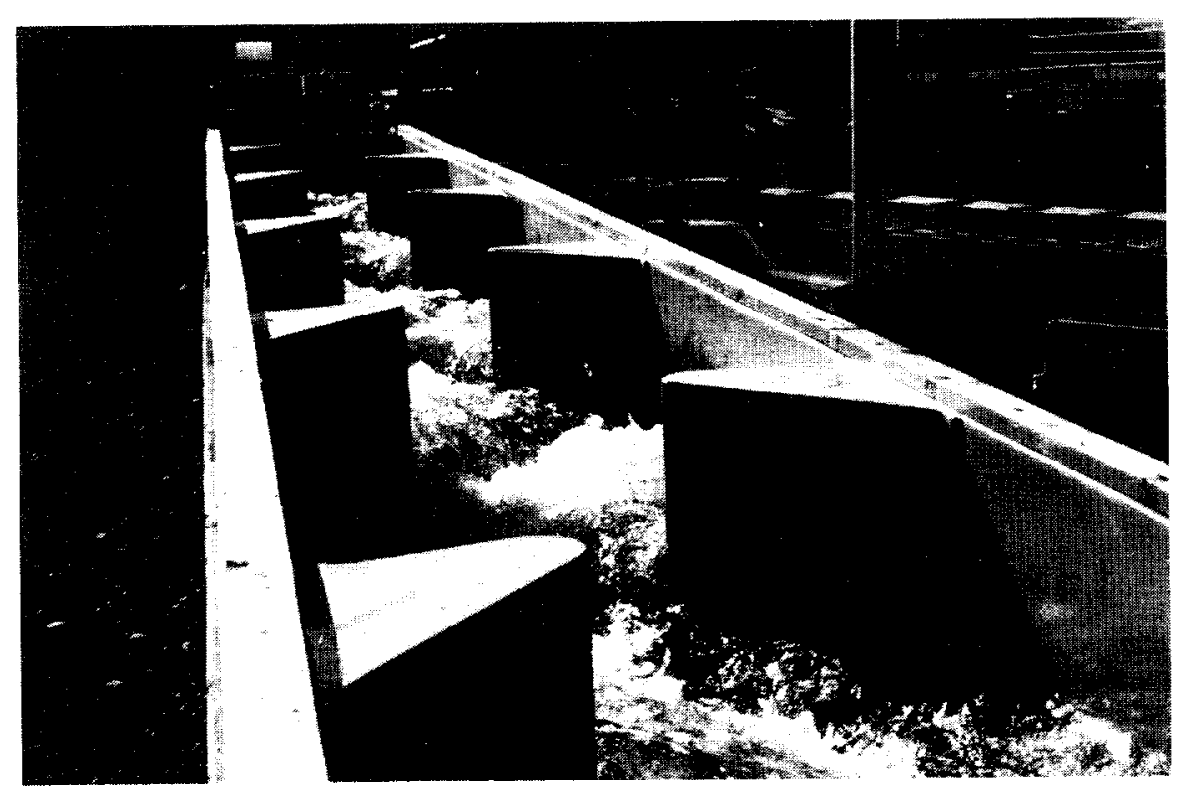

LOOKING UPSTREAM

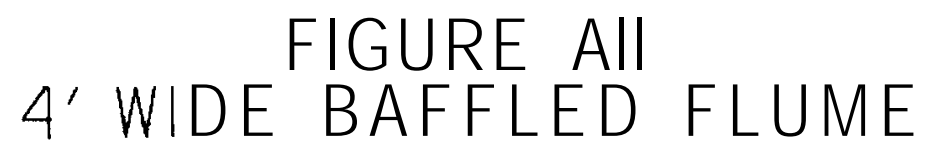




\section{APPENDIX B}

Analysis of Variance Tables for Selected Statistical Tests

1. Comparison of cortisol concentrations in all baseline samples of chinook salmon.

\begin{tabular}{lrlcrc} 
Source & DF & \multicolumn{1}{c}{ SS } & MS & F & P \\
\hline Light (A) & 2 & $2.13 E+04$ & $1.067 \mathrm{E}+04$ & 13.22 & 0.0001 \\
Flume (B) & 2 & 1090.1 & 545.06 & .68 & 0.5184 \\
Rep (C) & 6 & $3.801 \mathrm{E}+04$ & 6335.9 & 7.85 & 0.0001 \\
A*B & 4 & $1.147 \mathrm{E}+04$ & 2866.5 & 3.55 & 0.0206 \\
$\mathrm{~A} * \mathrm{C}$ & 12 & $1.211 \mathrm{E}+04$ & 1009.6 & 1.25 & 0.3077 \\
$\mathrm{~B} * \mathrm{C}$ & 12 & $1.548 \mathrm{E}+04$ & 1289.8 & 1.60 & 0.1585 \\
$\mathrm{~A} * \mathrm{~B} * \mathrm{C}$ & 24 & $1.937 \mathrm{E}+04$ & 807.1 & & \\
\hline \multicolumn{1}{c}{ TOTAL } & 62 & $1.189 \mathrm{E}+05$ & & &
\end{tabular}

2. Comparison of cortisol concentrations in chinook salmon between flumes and between light conditions using values calculated by subtracting an average night or day baseline value from each postpassage sample.

\begin{tabular}{lrccrc} 
Source & DF & SS & MS & F & P \\
\hline Light (A) & 2 & $4.307 \mathrm{E}+04$ & $2.154 \mathrm{E}+04$ & 18.79 & 0.0000 \\
Flume (B) & 2 & 139.16 & 69.58 & 0.06 & 0.9412 \\
Rep (C) & 6 & $4.808 \mathrm{E}+04$ & 8013.7 & 6.99 & 0.0002 \\
A*B & 4 & 6139.6 & 1534.9 & 1.34 & 0.2843 \\
A*C & 12 & $1.039 E+04$ & 865.8 & 0.76 & 0.6871 \\
B*C & 12 & $2.153 E+04$ & 1794.3 & 1.57 & 0.1690 \\
A*B*C & 24 & $2.751 E+04$ & 1146.2 & & \\
\hline \multicolumn{1}{c}{ TOTAL } & 62 & $1.569 E+05$ & & &
\end{tabular}

3. Comparison of cortisol concentrations in chinook salmon passing through darkened or partially darkened flumes during the day.

\begin{tabular}{lrlrrr}
\multicolumn{1}{c}{ Source } & DF & \multicolumn{1}{c}{ SS } & MS & F & P \\
\hline Dark vs Part. & & & & & \\
$\quad$ Dark & 1 & 4549.2 & 4549.2 & 6.07 & 0.0299 \\
Flume (B) & 2 & 295.2 & 147.6 & 0.20 & 0.8239 \\
Rep (C) & 6 & $3.679 E+04$ & 6132.1 & 8.18 & 0.0011 \\
A*B & 2 & 4240.6 & 2120.3 & 2.83 & 0.0986 \\
A*C & 6 & 2501.9 & 417.0 & 0.56 & 0.7571 \\
B*C & 12 & 5705.4 & 475.4 & 0.63 & 0.7793 \\
A*B*C & 12 & 8998.2 & 749.8 & & \\
\hline TOTAL & 62 & $6.308 E+04$ & & &
\end{tabular}


4. Comparison of baseline and postpassage cortisol concentrations in chinook salmon.

\begin{tabular}{|c|c|c|c|c|c|}
\hline Source & DF & ss & MS & $\mathbf{F}$ & $\underline{P}$ \\
\hline $\begin{array}{l}\text { Light (A) } \\
\text { Flume (B) }\end{array}$ & $\begin{array}{l}2 \\
2\end{array}$ & $\begin{array}{r}6820.5 \\
286.7\end{array}$ & $\begin{array}{r}3410.2 \\
143.4\end{array}$ & $\begin{array}{l}3.33 \\
0.14\end{array}$ & $\begin{array}{l}0.0538 \\
0.8702\end{array}$ \\
\hline $\begin{array}{l}\text { BL vs PP (C) } \\
\text { Rep (D) }\end{array}$ & $\begin{array}{l}1 \\
6\end{array}$ & $\begin{array}{c}1694.5 \\
8.095 E+04\end{array}$ & $\begin{array}{l}1694.5 \\
1.349 \mathrm{E}+04\end{array}$ & $\begin{array}{r}1.65 \\
13.16\end{array}$ & $\begin{array}{l}0.2113 \\
0.0000\end{array}$ \\
\hline$A * B$ & 4 & 4921.6 & 1230.4 & 1.20 & 0.3374 \\
\hline$A * C$ & 2 & $2.190 \mathrm{E}+04$ & $1.095 \mathrm{E}+04$ & 10.68 & 0.0005 \\
\hline$A * D$ & 12 & 9916.8 & 826.4 & 0.81 & 0.6418 \\
\hline$B * C$ & 2 & 895.0 & 447.5 & 0.44 & 0.6515 \\
\hline$B * D$ & 12 & $2.081 E+04$ & 1734.3 & 1.69 & 0.1345 \\
\hline$C * D$ & 6 & 4456.9 & 742.8 & 0.72 & 0.6342 \\
\hline$A * B * C$ & 4 & $1.233 E+04$ & 3082.6 & 3.01 & 0.0392 \\
\hline$A \star B \star D$ & 24 & $2.189 E+04$ & 911.9 & 0.89 & 0.6115 \\
\hline$A \star C \star D$ & 12 & $1.192 \mathrm{E}+04$ & 993.0 & 0.97 & 0.5035 \\
\hline$B * C * D$ & 12 & $1.495 \mathrm{E}+04$ & 1245.7 & 1.22 & 0.3306 \\
\hline$A * B * C * D$ & 23 & $2.357 E+04$ & 1025.0 & & \\
\hline TOTAL & 124 & $2.373 E+05$ & & & \\
\hline
\end{tabular}

5. Comparison of cortisol concentrations in chinook salmon postpassage samples (no baseline value subtracted).

\begin{tabular}{lrcrrr} 
Source & DF & SS & MS & F & P \\
\hline Light (A) & 2 & 49584.0 & 4792.0 & 4.93 & 0.0166 \\
Flume (B) & 2 & 184.3 & 92.2 & 0.09 & 0.9099 \\
Rep (C) & 6 & $4.454 \mathrm{E}+04$ & 7423.5 & 7.63 & 0.0001 \\
A*B & 4 & 4491.9 & 1123.0 & 1.15 & 0.3563 \\
A*C & 12 & 8060.7 & 671.7 & 0.69 & 0.7439 \\
B*C & 12 & $1.532 \mathrm{E}+04$ & 1276.9 & 1.31 & 0.2767 \\
A*B*C & 24 & $2.237 \mathrm{E}+04$ & 972.5 & & \\
\hline \multicolumn{1}{c}{ TOTAL } & 62 & $1.045 \mathrm{E}+05$ & & &
\end{tabular}

6. Comparison of baseline cortisol concentrations in steelhead smolts.

\begin{tabular}{|c|c|c|c|c|c|}
\hline Source & $\mathrm{DF}$ & ss & MS & $\mathbf{F}$ & $\mathbf{P}$ \\
\hline Light (A) & 2 & $3.107 E+04$ & $1.553 \mathrm{E}+04$ & 8.92 & 0.0016 \\
\hline Flume (B) & 2 & 7366.8 & 3683.4 & 2.11 & 0.1456 \\
\hline Rep (C) & 6 & $4.770 E+04$ & 7949.5 & 4.56 & 0.0041 \\
\hline$A * B$ & 4 & $1.220 \mathrm{E}+04$ & 3049.2 & 1.75 & 0.1767 \\
\hline$A * C$ & 12 & $3.130 E+04$ & 2608.1 & 1.50 & 0.2018 \\
\hline$B * C$ & 12 & $1.770 E+04$ & 1475.2 & 0.85 & 0.6065 \\
\hline$A * B * C$ & 21 & $3.658 E+04$ & 1741.8 & & \\
\hline TOTAL & 59 & $1.839 \mathrm{E}+05$ & & & \\
\hline
\end{tabular}


7. Comparison of baseline and postpassage cortisol concentrations in steelhead smolts.

\begin{tabular}{lrlrrr}
\multicolumn{1}{c}{ Source } & DF & \multicolumn{1}{c}{ SS } & \multicolumn{1}{c}{ MS } & \multicolumn{1}{c}{ F } & \multicolumn{1}{c}{ P } \\
\hline & & & & & \\
BL vs PP(A) & 1 & $8.402 E+04$ & $8.402 E+04$ & 140.25 & 0.0000 \\
Flume (B) & 2 & 1229.4 & 614.7 & 1.03 & 0.3878 \\
Rep (C) & 6 & $7.928 E+04$ & $1.321 E+04$ & 22.05 & 0.0000 \\
A*B & 2 & 8429.6 & 4214.8 & 7.04 & 0.0095 \\
$A * C$ & 6 & $1.857 E+04$ & 3094.8 & 5.17 & 0.0077 \\
$B \star C$ & 12 & $1.279 E+04$ & 1066.0 & 1.78 & 0.1658 \\
$A \star B \star C$ & 12 & 7189.3 & 599.1 & & \\
\hline \multicolumn{1}{c}{ TOTAL } & 41 & $2.115 E+05$ & & &
\end{tabular}

8. Comparison of steelhead cortisol concentrations between flumes and light conditions using values derived by subtracting an average daytime or nighttime baseline value from each postpassage sample.

\begin{tabular}{lrllrc}
\multicolumn{1}{c}{ Source } & DF & \multicolumn{1}{c}{ SS } & \multicolumn{1}{c}{$M S$} & \multicolumn{1}{c}{ F } & \multicolumn{1}{c}{ P } \\
\hline Light (A) & 2 & 8030.1 & 4015.0 & 4.74 & 0.0184 \\
Flume (B) & 2 & $3.048 E+04$ & $1.524 E+04$ & 18.01 & 0.0000 \\
Rep (C) & 6 & $1.105 E+04$ & $1.842 E+04$ & 21.77 & 0.0000 \\
A*B & 4 & 7811.5 & 1952.9 & 2.31 & 0.0873 \\
A*C & 12 & $3.375 E+04$ & 2812.4 & 3.32 & 0.0059 \\
B*C & 12 & $1.6975+04$ & 1414.5 & 1.67 & 0.1373 \\
A*B*C & 2 & $4.031 E+04$ & 846.4 & & \\
\hline \multicolumn{1}{c}{ TOTAL } & 62 & $2.279 E+05$ & & &
\end{tabular}

9. Comparison of cortisol concentrations in steelhead postpassage samples (no baseline value subtracted).

\begin{tabular}{lrllrr}
\multicolumn{1}{c}{ Source } & DF & \multicolumn{1}{c}{ SS } & \multicolumn{1}{c}{ MS } & \multicolumn{1}{c}{ F } & \multicolumn{1}{c}{ P } \\
\hline Light (A) & 2 & 3778.7 & 1889.4 & 2.23 & 0.1291 \\
Flume (B) & 2 & $3.048 \mathrm{E}+04$ & $1.524 \mathrm{E}+04$ & 18.01 & 0.0000 \\
Rep (C) & 6 & $1.105 \mathrm{E}+05$ & $1.842 \mathrm{E}+04$ & 21.77 & 0.0000 \\
A*B & 4 & 7811.5 & 1952.9 & 2.31 & 0.0873 \\
A*C & 12 & $3.375 \mathrm{E}+04$ & 2812.4 & 3.32 & 0.0059 \\
B*C & 12 & $1.697 \mathrm{E}+04$ & 1414.5 & 1.67 & 0.1373 \\
A*B*C & 2 & $42.031 \mathrm{E}+04$ & 846.4 & & \\
\hline \multicolumn{1}{c}{ TOTAL } & 62 & $\mathbf{2 . 2 3 6 E + 0 5}$ & & &
\end{tabular}


10. Comparison of the number of chinook remaining in each of the three flumes $20 \mathrm{~min}$ after release.

\begin{tabular}{lrcccc}
\multicolumn{1}{c}{ Source } & DF & SS & MS & F & P \\
\hline & & & & & \\
Light (A) & 2 & $1.149 e+04$ & 5747.3 & 1.82 & 0.1843 \\
Flume (B) & 2 & $4.971 E+04$ & $2.485 E+04$ & 7.85 & 0.0024 \\
Rep (C) & 6 & $2.628 E+05$ & 4380.5 & 1.38 & 0.2612 \\
A*B & 4 & $1.155 e+04$ & 2887.5 & 0.91 & 0.4727 \\
A*C & 12 & $3.142 E+04$ & 2618.0 & 0.83 & 0.6232 \\
B*C & 12 & $3.254 E+04$ & 2711.4 & 0.86 & 0.5972 \\
A*B*C & 24 & $7.596 E+04$ & 3164.9 & & \\
\hline
\end{tabular}

TOTAL $\quad 62 \quad 2.389 E+05$

11. Comparison of cortisol concentrations in chinook salmon held in darkened and partially darkened tanks and sampled during each of 3 days and nights.

\begin{tabular}{|c|c|c|c|c|c|}
\hline Source & DF & ss & MS & $\mathbf{F}$ & $\underline{P}$ \\
\hline $\begin{array}{l}\text { Night vs Day }(\mathrm{A}) \\
\text { Dark vs Partially }\end{array}$ & 1 & 3657.3 & 3657.3 & 29.56 & 0.0122 \\
\hline Dark (B) & 1 & 173.0 & 173.0 & 1.40 & 0.3222 \\
\hline Rep & 1 & 912.1 & 456.1 & 3.69 & 0.1556 \\
\hline Day (D) & 2 & 5782.1 & 2891.1 & 23.37 & 0.0148 \\
\hline$A * B$ & 2 & 155.7 & 155.7 & 1.26 & 0.3436 \\
\hline$A * C$ & 1 & 1376.5 & 688.2 & 5.56 & 0.0979 \\
\hline$A * D$ & 2 & 3868.0 & 1934.0 & 15.63 & 0.0259 \\
\hline$B * C$ & 2 & 1811.8 & 905.9 & 7.32 & 0.0701 \\
\hline$B * D$ & 2 & 1095.5 & 547.7 & 4.43 & 0.1273 \\
\hline$C \star D$ & 4 & 5685.0 & 1421.2 & 11.49 & 0.0365 \\
\hline$A \star B \star C$ & 2 & 747.3 & 373.6 & 3.02 & 0.1912 \\
\hline$A \star B * D$ & 2 & 2330.0 & 1165.0 & 9.42 & 0.0509 \\
\hline$A * C * D$ & 4 & $1.002 \mathrm{E}+04$ & 2506.4 & 20.26 & 0.0165 \\
\hline$B * C * D$ & 4 & 4430.3 & 1107.6 & 8.95 & 0.0512 \\
\hline$A * B * C \star D$ & 3 & 371.2 & 123.7 & & \\
\hline
\end{tabular}

TOTAL

$344.242 \mathrm{E}+04$ 
12. Comparison of cortisol concentrations in chinook salmon held in darkened and partially darkened raceways, sampled during the day or night.

\begin{tabular}{llllll} 
Source & DF & SS & MS & F & P \\
\hline
\end{tabular}

\begin{tabular}{lrrrrr}
$\begin{array}{l}\text { Day vs Night (A) } \\
\text { Dark vs Partially }\end{array}$ & 1 & $1.493 E+04$ & $1.493 E+04$ & 27.44 & 0.0135 \\
Dark (B) & 1 & 548.6 & 548.6 & 1.01 & 0.3892 \\
Day (D) & 3 & 4600.4 & 1533.5 & 2.82 & 0.2087 \\
Rep (D) & 1 & 4776.6 & 4776.6 & 8.78 & 0.0594 \\
A*B & 1 & 26.3 & 26.3 & 0.05 & 0.8400 \\
A*C & 3 & 1788.2 & 596.1 & 1.10 & 0.4709 \\
A*D & 1 & 138.1 & 138.1 & 0.25 & 0.6491 \\
B*C & 3 & 5735.1 & 1911.7 & 3.51 & 0.1647 \\
B*D & 1 & 146.0 & 146.0 & 0.27 & 0.6402 \\
C*D & 3 & 1085.4 & 361.8 & 0.67 & 0.6272 \\
A*B*C & 3 & 6471.4 & 2157.1 & 3.97 & 0.1438 \\
A*B*D & 1 & 145.7 & 145.7 & 0.27 & 0.6405 \\
A*C*D & 3 & 2193.5 & 731.2 & 1.34 & 0.4069 \\
B*C*D & 3 & 477.2 & 159.1 & 0.29 & 0.8302 \\
A*B*C*D & 3 & 1631.9 & 544.0 & & \\
\hline TOTAL & 31 & $4.469 E+04$ & & &
\end{tabular}

13. Comparison of cortisol concentrations in steelhead smolts held in tanks receiving four different light intensities.

\begin{tabular}{lrcrrr} 
Source & DF & SS & \multicolumn{1}{c}{ MS } & F & \multicolumn{1}{c}{ P } \\
Light (A) & 3 & 9812.8 & 3270.9 & 2.90 & 0.1240 \\
Rep (B) & 1 & 9.0 & 9.0 & 0.01 & 0.9318 \\
Subrep (C) & 2 & 7612.4 & 3806.2 & 3.37 & 0.1045 \\
A*B & 3 & 2392.8 & 797.6 & 0.71 & 0.5824 \\
A*C & 6 & $1.720 E+04$ & 2866.6 & 2.54 & 0.1409 \\
B*C & 2 & 350.9 & 175.5 & 0.16 & 0.8595 \\
A*B*C & 6 & 6777.3 & 1129.5 & & \\
\hline \multicolumn{1}{c}{ TOTAL } & 23 & $4.415 E+04$ & & &
\end{tabular}


14. Comparison of cortisol concentrations in chinook smolts held individually in compartments within darkened and partially darkened tanks and sampled during the day or night.

\begin{tabular}{|c|c|c|c|c|c|}
\hline Source & $\mathrm{DF}$ & ss & MS & $\underline{\mathbf{F}}$ & $\mathbf{P}$ \\
\hline Light vs Dark (A) & 1 & 102.76 & 102.76 & 0.15 & 0.7119 \\
\hline Rep & 3 & $3.201 E+04$ & $1.067 E+04$ & 15.57 & 0.0031 \\
\hline Night vs Day (C) & 1 & $5.167 \mathrm{E}+04$ & $5.167 \mathrm{E}+04$ & 75.42 & 0.0001 \\
\hline Tank (D) & 2 & 1587.3 & 793.7 & 1.16 & 0.3755 \\
\hline$A * B$ & 3 & $1.028 \mathrm{E}+04$ & 3426.8 & 5.00 & 0.0452 \\
\hline$A * C$ & 1 & $2.488 E+04$ & $2.488 E+04$ & 36.31 & 0.0009 \\
\hline$A * D$ & 2 & 7148.8 & 3574.4 & 5.22 & 0.0487 \\
\hline$B * C$ & 3 & $6.672 \mathrm{E}+04$ & $2.224 \mathrm{E}+04$ & 32.46 & 0.0004 \\
\hline$B * D$ & 6 & $1.137 E+04$ & 1894.9 & 2.77 & 0.1206 \\
\hline$C \star D$ & 2 & 3650.0 & 1825.0 & 2.66 & 0.1486 \\
\hline$A * B * C$ & 3 & $1.171 E+04$ & 3902.7 & 5.70 & 0.0344 \\
\hline$A * B * D$ & 6 & 9066.5 & 1511.1 & 2.21 & 0.1793 \\
\hline$A \star C \star D$ & 2 & 1734.7 & 867.4 & 1.27 & 0.3478 \\
\hline$B \star C * D$ & 6 & $1.652 \mathrm{E}+04$ & 2753.1 & 4.02 & 0.0573 \\
\hline$A * B * C \star D$ & 6 & 4111.0 & 685.2 & & \\
\hline TOTAL & 47 & $2.526 E+05$ & & & \\
\hline
\end{tabular}




\section{APPEND X C}

Summary of Pl asma Corti sol Concentration Data for 1985 and 1987 Fl une Tests

Tabl e 1. Compari son of mean basel i ne and post passage pl asma corti sol concentrations ( $\mathrm{ng} / \mathrm{mL}$ ) i n spring chi nook sal mon snol ts used in 1985 and $1987^{2}$. fl une tests.

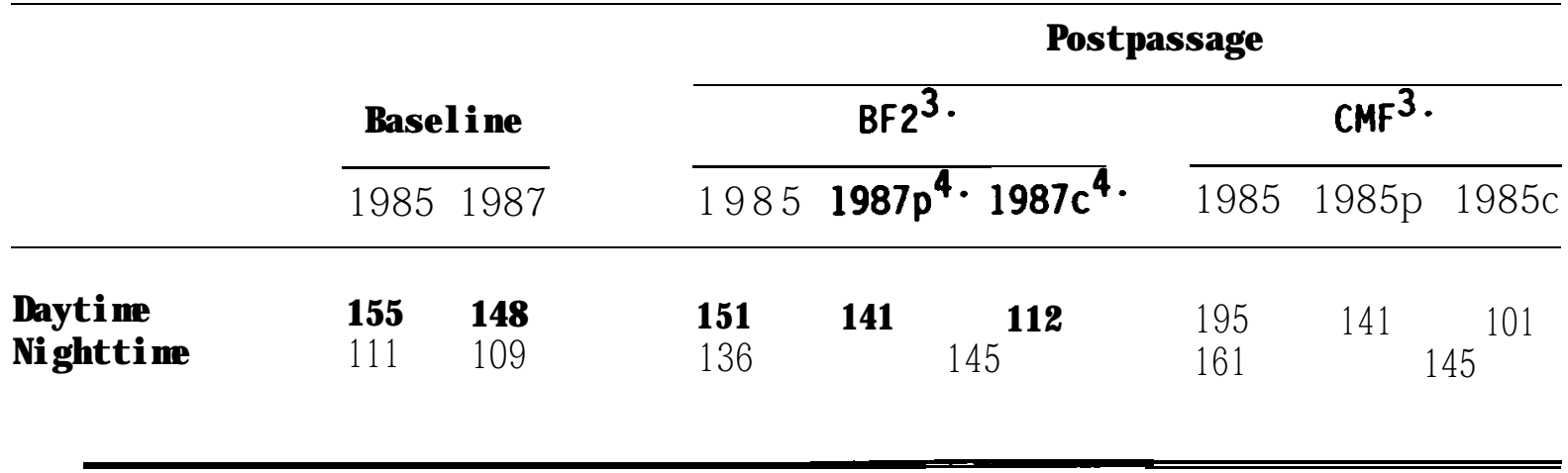

Table 2. Compari son of basel i ne and postpassage pl asma corti sol concent rati ons ( $\mathrm{ng} / \mathrm{mL}$ ) i n steel head trout snol ts used i $\mathrm{n} 1985^{1}$ and $1987^{2}$. fl une tests.

\begin{tabular}{|c|c|c|c|c|c|}
\hline & & \multicolumn{4}{|c|}{ Post passage } \\
\hline & Basel i ne & \multicolumn{2}{|r|}{$\mathrm{BF}^{3}$} & \multicolumn{2}{|r|}{$\mathrm{CMF}^{3}$} \\
\hline & 19851987 & 1985 & $1987 p^{4} \cdot 1987 c^{4}$ & 1985 & $1987 \mathrm{p} 1987 \mathrm{c}$ \\
\hline $\begin{array}{l}\text { Dayt i me } \\
\text { N ghtti me }\end{array}$ & $\begin{array}{ll}194 & 212 \\
\mathbf{1 4 4} & \mathbf{1 7 4}\end{array}$ & $\begin{array}{l}274 \\
284\end{array}$ & $297 \quad 289^{316}$ & $\begin{array}{l}336 \\
264\end{array}$ & $2322^{248}{ }^{261}$ \\
\hline
\end{tabular}


Tabl e 3. Comparison of net changes in plasm corti sol concentrations ( post passage - basel i ne i $\mathbf{n g} / \mathbf{m L}$ ) in chi nook sal non and steel head trout smolts used in $1985^{1}$ and $1987^{2}$. flume tests.

\begin{tabular}{|c|c|c|c|c|c|c|c|}
\hline & \multicolumn{4}{|c|}{$\mathrm{BF} 2^{3}$} & \multicolumn{3}{|c|}{$\mathrm{CMF}^{3}}$. \\
\hline & 1985 & 1987 & $p^{4} \cdot 1$ & $987 c^{4}$ & 1985 & $1987 p$ & $1987 \mathrm{c}$ \\
\hline $\begin{array}{l}\text { Chi nook Sal mon } \\
\text { Dayt i me } \\
N \text { ght i me }\end{array}$ & $\begin{array}{l}-4 \\
25\end{array}$ & -7 & 36 & -36 & $\begin{array}{l}40 \\
50\end{array}$ & -7 & $36^{-47}$ \\
\hline $\begin{array}{l}\text { St eel head Trout } \\
\text { Paytht tene }\end{array}$ & $\begin{array}{r}80 \\
140\end{array}$ & 85 & 115 & 104 & $\begin{array}{l}142 \\
120\end{array}$ & 20 & $74 \quad 49$ \\
\hline
\end{tabular}

1. Reported i n Congl et on and Ri nge (1985); 4-5 tests compl et ed.

2. Present study; 7 tests compl eted.

3. $B F 2$ = baffled fl une, 2 feet in wi dth; $\mathrm{CMF}=$ corrugated net al $\mathbf{f l}$ une.

4. $1987 p=$ parti al I y darkened $\mathrm{fl}$ ume ( perforated metal cover); $1987 \mathrm{c}=$ compl et el y darkened fl une (opaque cover). 